Review

\title{
Molecular Approaches to Improve the Insecticidal Activity of Bacillus thuringiensis Cry Toxins
}

\author{
Wagner A. Lucena ${ }^{1,2,3, \dagger}$, Patrícia B. Pelegrini ${ }^{3, \dagger}$, Diogo Martins-de-Sa ${ }^{3,4}$, \\ Fernando C. A. Fonseca ${ }^{3,4}$, Jose E. Gomes Jr. ${ }^{3,4}$, Leonardo L. P. de Macedo ${ }^{3,5}$, \\ Maria Cristina M. da Silva ${ }^{3}$, Raquel S. Oliveira ${ }^{3,5}$ and Maria F. Grossi-de-Sa ${ }^{3,5, *}$
}

1 Embrapa Cotton, Campina Grande, 58428-095, PB, Brazil; E-Mail: wagner.lucena@embrapa.br

2 Graduate Program in Cellular and Molecular Biology, Federal University of Rio Grande do Sul, Porto Alegre, 91501-970, RS, Brazil

3 Embrapa Genetic Resources and Biotechnology, Brasília, 70779-917, DF, Brazil; E-Mails: pbpelegrini@gmail.com (P.B.P.); dmartinsdesa@gmail.com (D.M.-S.); fcafonseca@gmail.com (F.C.A.F.); jose_edilson@yahoo.com.br (J.E.G.); leonardo.lima@embrapa.br (L.L.P.M.); cristina.mattar@embrapa.br (M.C.M.S.); raquelsam@gmail.com (R.S.)

4 Department of Molecular Biology, Federal University of Brasília, Brasília, 70910-900, DF, Brazil

5 Post-Graduation of Genomic Sciences and Biotechnology, Catholic University of Brasilia, Brasília, 70790-160, DF, Brazil

$\dagger$ These authors contributed equally to this work.

* Author to whom correspondence should be addressed; E-Mail: fatima.grossi@embrapa.br; Tel.: +55-61-3448-4705; Fax: +55-61-3448-3624.

Received: 14 May 2014; in revised form: 23 June 2014 / Accepted: 27 June 2014 / Published: 13 August 2014

\begin{abstract}
Bacillus thuringiensis (Bt) is a gram-positive spore-forming soil bacterium that is distributed worldwide. Originally recognized as a pathogen of the silkworm, several strains were found on epizootic events in insect pests. In the 1960s, Bt began to be successfully used to control insect pests in agriculture, particularly because of its specificity, which reflects directly on their lack of cytotoxicity to human health, non-target organisms and the environment. Since the introduction of transgenic plants expressing Bt genes in the mid-1980s, numerous methodologies have been used to search for and improve toxins derived from native Bt strains. These improvements directly influence the increase in productivity and the decreased use of chemical insecticides on
\end{abstract}


Bt-crops. Recently, DNA shuffling and in silico evaluations are emerging as promising tools for the development and exploration of mutant Bt toxins with enhanced activity against target insect pests. In this report, we describe natural and in vitro evolution of Cry toxins, as well as their relevance in the mechanism of action for insect control. Moreover, the use of DNA shuffling to improve two Bt toxins will be discussed together with in silico analyses of the generated mutations to evaluate their potential effect on protein structure and cytotoxicity.

Keywords: Cry toxins; insect pests; biocontrol; evolution; phage, display, DNA shuffling; in silico studies; specific mutation

\section{Introduction}

Cry toxins or $\delta$-endotoxins secreted by the gram-positive bacterium Bacillus thuringiensis (Bt) are effectively applied to control crop pests and disease vectors due to their specificity and toxicity toward certain insect orders. The mechanism of action of Cry toxins has been extensively reported, and two main theories have been developed to understand how these proteins act on the midgut of several insect species [1-3]. The tertiary structures of nine Cry toxins (Cry1Aa, Cry34Ab1, Cry1Ac, Cry2Aa, Cry3Aa, Cry3Bb1, Cry4Aa, Cry5B, and Cry8Ea1) have been determined by X-ray crystallography [4-11], and the structures confirm their conserved organization into three domains. Domain I is composed of seven antiparallel $\alpha$-helices. The central hydrophobic helix $(\alpha 5)$ is surrounded by amphipathic helices [4] and is involved in membrane pore formation. Domain II is organized into three antiparallel $\beta$-sheets and two shorter $\alpha$-helices; this domain is related to receptor binding specificity [12]. Moreover, Domain III includes the $C$-terminus of most of Cry toxins and consists of two antiparallel $\beta$-sheets. Domain III, together with domain II, is responsible for structural stability and interaction with insect receptors [6]. Insects exhibit high genetic diversity and acquire resistance to diverse control strategies. Therefore, new approaches for the development of novel molecules with improved insecticidal activity are necessary and represent an important focus for biotechnological strategies. Additionally, the generation of insect resistant transgenic crops is not only one of the most widespread but also the most effective plant biotechnology applications worldwide.

In vitro directed evolution to improve the insecticidal activity of Cry toxins has been used with significant success [13-15]. In recent years, knowledge of the rate-limiting steps of Cry toxicity in different insect pests has considerably increased. Although the mechanism of action for Cry toxicity has not been completely elucidated, several studies have identified specific binding regions in the Cry toxins. Additionally, several mutagenesis strategies and selection procedures have been described. For example, in DNA shuffling approaches [16,17], the variants of an individual gene or a set of homologous genes are fragmented and recombined to give rise to genes with different base compositions.

Therefore, in this report, we briefly summarize the natural and in vitro evolution of Cry toxins and the contributions that improve the insecticidal activity of these toxins at the molecular level. Additionally, we describe the strategies used to obtain Cry variants from two different toxin families: 
Cry1I and Cry8Ka. Similarly, we discuss preliminary results from in silico evaluations of specific mutations from variants obtained using phage display and DNA shuffling techniques on three Cry toxins (Cry1A, Cry1Ia12 and Cry8Ka1) to determine their contribution on improved insecticidal activity and to direct the design of future studies to elucidate the mechanism of Cry toxins.

\section{Brief Insights into the Natural Evolution of Cry Toxins}

Of the Cry toxins studied to date, more than 700 genes have been identified, corresponding to proteins divided into approximately 70 different groups $[18,19]$. However, phylogenetic analyses have demonstrated that Cry toxins can be divided into four families that do not share phylogenicity [20]. Hence, Cry toxins can be classified as three-Domain crystal toxins (3D-Cry), mosquitocidal Cry toxins (Mtx), binary-like toxins (Bin) and cytolytic (Cyt) toxins [20].

Since the 1990s, the nomenclature of Cry toxins has been based on their amino acid sequence identity, and these toxins are classified according to a three-step procedure [18]. Toxins that share less than $45 \%$ identity in their primary sequence are identified by different Arabic numbers in their names. When Cry toxins exhibit amino acid sequence identity between $45 \%$ and $70 \%$, a capital letter is included after the number. Moreover, if the sequence identity between Cry toxins is from $70 \%$ to $95 \%$, a lowercase letter is added to the toxin name [18]. Cry toxins are also classified according to their specificity toward insect orders and/or nematode species.

Of the four families, 3D-Cry toxins (Cry toxins hereafter) represent the largest number of toxins and comprise over 50 distinct groups [19]. Cry toxins share high amino acid sequence identity and similar tertiary structures. Previous studies on the analysis of phylogenetic trees of protoxins and mature Cry toxins have indicated that, using protoxins for the phylogenetic tree, Cry1 proteins are grouped into one core cluster [21]. Moreover, the branch formed by Cryl toxins was clearly and sufficiently separate from other protoxins to classify them as a subdivision group in the phylogenetic tree. In contrast, Cry toxin groups, such as the Cry 8 and Cry9 protoxins, demonstrated an arrangement that was identical to that of the branch of Cry2 and Cry11 protoxins [21,22]. However, when the phylogenetic tree of active proteins was analyzed, different results were observed. The Cry1B, Cry1Ia and Cry1 Ib groups of toxins were not located in the branch of the general Cry1 toxin group but were placed with the cluster of toxins that exhibit insecticidal activity against Lepidoptera insects. This finding was expected, as toxins in the Cry1B, Cry1 Ia and Cry1Ib groups exhibit activity against this order of insect pests. In contrast, other Cryl toxins groups were unexpectedly and phylogenetically near a second cluster of proteins that exhibit insecticidal activity against Coleopteran insects. Therefore, the Cry1I and Cry1B groups may exhibit activity against coleopterans, in addition to the Cry3, Cry7 and Cry8 groups [21,22].

When an analysis of each Domain of Cry toxins was performed using phylogenetic trees, interesting results were observed. The tertiary structure of Cry1 Ab (Figure 1) reveals three Domains, with Domain I as the most conserved region in Cry toxins. Because this Domain is involved in membrane insertion and pore formation, it is suggested that Cry toxins maintained this region intact despite genetic variability, allowing modifications in other sites of the protein sequence and structure [23,24]. Nevertheless, some mutations that were found in native $\mathrm{Bt}$ strains are located in Domain II (specifically at three surface-exposed loops). These loops have been described as important sites for 
receptor recognition and binding $[25,26]$. Therefore, the positive selection observed in Loops 1,2 and 3 may be involved in the increase in specificity and interaction of Cry toxins with the different receptors located at the surface of insect cells [24].

Figure 1. Structure of an activated Cry1 Ab toxin. The three Domains are colored as follows: Domain I (red), Domain II (green), and Domain III (blue). Loop 1 is shown in cyan, loop 2 is shown in magenta, loop 3 is shown in black and loop $\alpha 8$ is shown in orange.

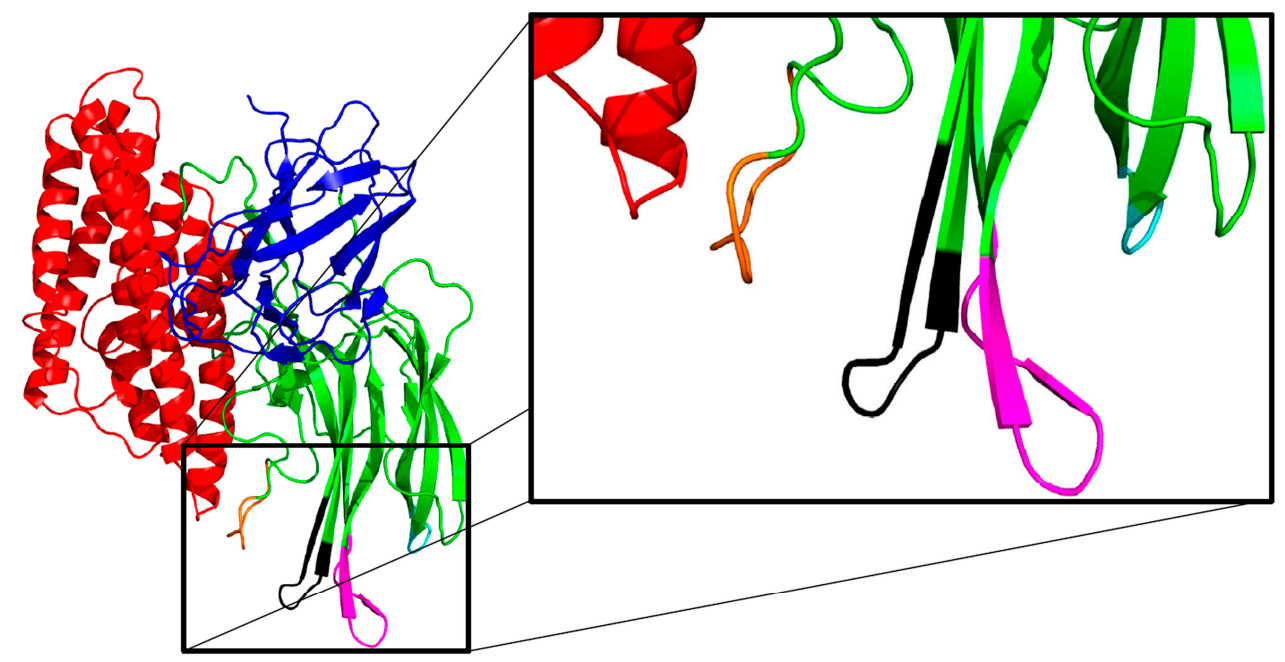

\section{Mechanism of Action}

Active toxins are able to bind receptors at the brush border membrane of midgut insect cells, inducing pore formation and cell death. The toxin/receptor interaction has been extensively characterized [27-36]. The high amino acid sequence identity among Cry toxins has led to the suggestion of a similar mode of action. However, the efficacy of Cry toxins is dependent on the recognition of a specific receptor, as well as on protein oligomerization and the activation of protoxins by insect proteases $[2,25,30]$. Different cell surface receptors, such as cadherins, aminopeptidases (APNs) and alkaline phosphatases (ALPs), have been described that recognize Cry toxins and are responsible for the susceptibility of several insect species.

Although extensively studied, the mechanism of action of Cry toxins remains poorly defined, particularly with regard to how specific residues and Domains in these proteins respond following binding to an insect cell receptor. Briefly, it has been suggested that following ingestion by insect pests, Cry toxins are activated after solubilization by midgut proteases and interact with different receptors located at the surface of the epithelial cells [3,30,36-40]. This interaction leads to a conformational change that facilitates protein oligomerization and insertion into the membrane. An increase in membrane permeability follows, resulting in cell death [3,30,36-40].

Another theory suggests that, following binding to a specific cell receptor, Cry toxins stimulate a signaling pathway involving $G$ proteins and adenylyl cyclase, which activate cAMP and protein kinase A, leading to cell and insect death [2].

Previous studies have revealed that the recognition of Cry toxins by cell surface receptors occurs in different regions of the protein. Monomeric active CrylAb toxin has been described to interact with ALPs and APNs via loop 3 of Domain II and $\beta 16$ of Domain III. In contrast, the oligomeric form of 
Cry1 Ab binds ALP and APN via loop 2 of Domain II [35,41]. In addition, Cry1 Ab binds cadherin receptors via loops 2 and 3 and $\alpha 8$ of Domain II $[42,43]$. Therefore, an understanding of the specific regions and residues involved in the mechanism of action of Cry toxins with different cell surface receptors will enable the design of novel molecules with improved activity for insect biocontrol.

\section{Biotechnology Strategies to Speed in Vitro Molecular Evolution of Cry Toxins}

Phage display and DNA shuffling techniques have been widely used on Cry toxins to explore specific residues and interaction sites involved in their insecticidal activity. Thus, among Cry1A toxins, phage display assays have been utilized using different phage libraries, such as M13 and T7, although studies using M13 phages have demonstrated greater efficiency than those using T7 phages [44-47]. Using this approach, novel toxins have been generated that exhibit improved activity toward specific insect pests. Previous studies have reported the construction of a library of CrylAa toxin Domain II Loop 2 sequences that was displayed on T7 phages and used to evaluate the binding affinity toward the Bombyx mori cadherin receptor [48]. After five rounds of selection, a Cry1Aa mutant containing a mutated Loop 2 in Domain II was obtained that exhibited a 6-fold increase in the insecticidal activity against $B$. mori, indicating that mutations in this region may affect Cry toxin binding to the receptor [48].

Furthermore, Lassner and Bedbrook [49] reported that the spectrum of insects controlled by Bt Cry toxins could be broadened using a DNA shuffling strategy. These authors used Cry1Ca and Cry1Ab, which are parental toxins originally ineffective for the control of Spodoptera sp. The resultant Cry1Ca-shuffled library genes were screened for activity against $S$. exigua. A Bt variant improved the activity (3.8 fold) against $S$. exigua in comparison to the original gene sequence, demonstrating the effectiveness of DNA shuffling to improve the insecticidal activity of Cry toxins for the control of insect pests. Using a different strategy, another study demonstrated that shuffling of Cry coding regions is an effective tool to generate diverse chimeric Cry proteins [50]. Moreover, chimeras containing mutations in Domain III of Cry proteins demonstrated higher activity against Lucilia cuprina and Epiphyas postvittana [50]. A crylAc gene was modified using error-prone PCR and staggered extension process (StEP) shuffling combined with Red/ET homologous recombination to evaluate the insecticidal activity of CrylAc [51]. The CrylAc toxin variant screened using an insect bioassay exhibited increased (1.4 fold, $\mathrm{LC}_{50}$ ) insecticidal activity against $S$. exigua larvae, whereas the original insecticidal activity against Helicoverpa armigera larvae was retained. Based on these results, these authors concluded that mutations in Domain III of CrylAc, particularly those located in the loop between $\beta 16$ and $\beta 17$, are essential for the insecticidal activity against insect pests. Using a different method for directed evolution of Cry toxins, consisting of a combination of error-prone PCR, staggered extension process (StEP) shuffling and Red/ET homologous recombination, these authors [51] sought to increase the Cry toxin binding affinity for the insect receptor. Random mutations were introduced in residues in Domain II of the Cry1Aa toxin, the mutant toxins were expressed on phages, and the resultant library was screened using cadherin-like protein-coated beads. Phages expressing abnormal or low-affinity mutant toxins were excluded, and phages with high-affinity mutant toxins were selected. The results indicated that a method combining T7 phage display with selection using cadherin-like protein-coated magnetic beads could be used to increase the 
activity of Cry toxins [48]. More recently, Fuji et al. [52] generated mutant toxins with improved binding affinity against Bombyx mori cadherin-like receptor (BtR175) using directed evolution. Four serial residues of Cry1Aa were replaced with random amino acids and were displayed on T7 phages for library construction. Through five cycles of panning of the phage libraries using BtR175, 11 mutant phage clones were selected, and mutant toxin sequences were evaluated. The binding affinities of the three mutants were 42-, 15-, and 13-fold higher than that of the wild type, indicating that mutants with improved binding affinity to cadherin can be easily selected from randomly replaced loop 3 mutant libraries using in vitro directed evolution.

Although phage display assays in combination with DNA shuffling have been successfully used to improve Cry toxins, site-directed mutations generated in the variants have also been investigated using in silico analyses. To better understand the implications of different mutations on the mechanism of action of Cry toxins, as well as their effect on insect pest control, bioinformatics tools are emerging as the methodology of choice. In time, in silico evaluations have transformed from a complementary methodology to an essential technique for the analysis of site-directed mutations, facilitating the selection of the optimal variant for a specific activity against a targeted pest.

\section{In Silico Analyses of Cry and Mutant Toxins for the Control of Economically Important Insect Pests}

\subsection{Cry1A: Effects of Amino Acid Modifications on Receptor Binding and Toxicity}

Despite the differences between the models for the Cry toxin mechanism of action, certain common characteristics can be noted. Mutagenesis studies have been used to understand the Cry toxin mechanism of action and as a tool for the discovery of specific sites to increase protein activity against insect pests. The activation of these proteins occurs via proteases present in the midgut juice of insect species, as well as by the interaction of Cry toxins with cell surface receptors, such as cadherins, which facilitate the removal of $\alpha$-helix $1(\alpha 1)$ of the toxins, allowing their oligomerization and subsequent insecticidal activity [37]. Previous studies have demonstrated that modified Cry1Ab and Cry1Ac, with prior $\alpha 1$ removal, were able to form oligomers in vitro in the absence of cadherin receptors, becoming toxic against Pectinophora gossypiella [53-55]. Additional studies revealed that a V171C mutation in alpha-helix $5(\alpha 5)$ of Cry1 Ab resulted in an increase in toxin activity against $L$. dispar due to a possible enhancement of the Cry1 Ab unfolding rate, resulting in easier integration into the membrane [54].

Cadherin receptor-binding sites in Cry toxins have been studied for several insect species. Loops 2 and 3 and $\alpha 8$ from Domain II have been identified among the regions involved in receptor binding [56,57] (Figure 1). Mutagenesis studies have been conducted to understand how these regions interact with the target receptors. A Y445C Cry1Aa mutation reduced binding to the BtR175 receptor, resulting in extremely reduced toxicity to Bombyx mori larvae [57], whereas an N372 deletion reduced binding and resulted in low larvae mortality [58]. An N372A mutation in Loop 2 of Cry1Ab exhibited enhanced activity against Lymantria dispar in in vitro assays. When the mutations A282G and L283S were also introduced, the toxicity against the Lepidoptera insect increased 36 fold in comparison with the wild type protein [58]. However, the loop 2 mutations N372A and N372G did not significantly alter Cry1 Ab binding to Lymantria dispar brush border membrane vesicles (BBMVs) [58]. 
The G439D CrylAb mutation was found to inhibit binding to Manduca sexta BBMVs and increased toxin activity by approximately 150 fold. However, care must be taken while conducting amino acid substitutions because some studies have shown that loops 1, 2, and 3 and $\alpha 8$ in Domain II are extremely flexible and are not dependent on amino acid conservation, which hampers efforts to obtain toxins with increased activity against the insects [52,59]. As another example, loop 3 of Domain II in Cry1Aa was substituted by an identical region in Cry4Aa, which exhibits activity against mosquito species. The variant Cry1 toxin demonstrated identical insecticidal toxicity to Culex pipiens larvae [60]. These results indicate that the exchange of loops from Domain II of different Cry toxins can add new specificities to the proteins and serves as a strategic tool for the improvement of toxins against targeted pests.

In addition, mutations in Domain III of Cry toxins have been described. A majority of the studies include the substitution of the entire Domain from one toxin with that of another. When Domain III of Cry1Ab was substituted with Domain III of Cry1C, the variant Cry1Ab toxin exhibited a sixfold enhanced activity against Spodoptera exigua compared with Cry1C [61]. Similarly, the exchange of Domain III of Cry1Ia with that of Cry1Ba resulted in a toxin that exhibited a threefold increase in the activity against the coleopteran Leptinotarsa decemlineata [62]. Because Cry1 Ab is toxic to lepidopteran insects, the introduction of its Domain III into the Cry3Aa toxin provided an efficient in vitro activity against Diabrotica virgifera (Coleoptera: Chrysomelidae) [63,64]. Therefore, the exchange of Domain III between Cry toxins can serve as an efficient technique to improve the insecticidal activity against several insect pest species. Recently, similar concepts have been applied using more robust strategies, such as phage display and shuffling of cry genes.

In the pore formation model, the glycosylphosphatidylinositol (GPI)-anchored proteins, APNs and ALPs have been shown to participate in the mechanism of action of Cry1A toxins. The interaction between the monomeric toxin with GPI-anchored proteins occurs via strand $\beta 16$ in Domain III of ALP [41] and via loop 2 and 3 in Domain II of APN [35,65]. Following oligomerization, binding to GPI-anchored proteins occurs via loop 2 in Domain II of the Bt toxin [41]. Site-directed mutagenesis has been used to mutate several residues in CrylA toxins (Table 1). Girard and coworkers [66] individually replaced 19 residues in helix $\alpha 4$ in Domain I of Cry1Aa. These authors observed that 10 mutants exhibited severely reduced activity against $M$. sexta larvae due to the inability to form pores in the cell membrane. This effect was observed after these residues were substituted by different amino acids [67]. Cry1 Ab helices $\alpha 3, \alpha 4, \alpha 5$ and $\alpha 6$ have been targeted for amino acid substitution. Helix $\alpha 3$ mutants were unable to form oligomers, preventing pore formation on the $M$. sexta larvae cell membrane [68]. Of eight helix $\alpha 4$ mutants, six exhibited a dominant negative phenotype, which competed with the wild-type Cry1 $\mathrm{Ab}$ toxin for oligomer assembly, resulting in reduced membrane insertion and low mortality of M. sexta larvae [69]. In addition, an N135Q Cry1Ac mutation in helix $\alpha 4$ in Domain I resulted in low oligomer assembly, suggesting inhibition of protein pore formation, and low mortality of M. sexta larvae [70]. 
Table 1. Site-directed mutations of Cry1 Aa, Cry1Ab and Cry1 Ac and their influence on toxins' function against insect pests.

\begin{tabular}{|c|c|c|c|c|c|c|}
\hline Toxin & Mutation & Region & Characteristic & Molecular effect & Toxicity & Reference \\
\hline \multirow{27}{*}{ Cry1Aa } & L126C & Helix $\alpha 4$ (domain I) & Reduced capacity to form pores & Low influx of ions & Extremely reduced & \multirow{27}{*}[66]{} \\
\hline & $\mathrm{R} 127 \mathrm{C}$ & Helix $\alpha 4$ (domain I) & Increased capacity to form pores & Increased influx of ions & Slightly reduced & \\
\hline & M130C & Helix $\alpha 4$ (domain I) & Increased capacity to form pores & Increased influx of ions & Slightly reduced & \\
\hline & $\mathrm{R} 131 \mathrm{C}$ & Helix $\alpha 4$ (domain I) & Highly reduced capacity to form pores & Extremely low influx of ions & Extremely reduced & \\
\hline & $\mathrm{I} 132 \mathrm{C}$ & Helix $\alpha 4$ (domain I) & Highly reduced capacity to form pores & Extremely low influx of ions & Reduced & \\
\hline & Q133C & Helix $\alpha 4$ (domain I) & Reduced capacity to form pores & Low influx of ions & Extremely reduced & \\
\hline & F134C & Helix $\alpha 4$ (domain I) & Increased capacity to form pores & Increased influx of ions & Reduced & \\
\hline & $\mathrm{N} 135 \mathrm{C}$ & Helix $\alpha 4$ (domain I) & Highly reduced capacity to form pores & Extremely low influx of ions & Extremely reduced & \\
\hline & M137C & Helix $\alpha 4$ (domain I) & Increased capacity to form pores & Increased influx of ions & Slightly reduced & \\
\hline & $\mathrm{N} 138 \mathrm{C}$ & Helix $\alpha 4$ (domain I) & Highly reduced capacity to form pores & Extremely low influx of ions & Extremely reduced & \\
\hline & $\mathrm{S} 139 \mathrm{C}$ & Helix $\alpha 4$ (domain I) & Highly reduced capacity to form pores & Extremely low influx of ions & Reduced & \\
\hline & $\mathrm{A} 140 \mathrm{C}$ & Helix $\alpha 4$ (domain I) & Highly reduced capacity to form pores & Extremely low influx of ions & Extremely reduced & \\
\hline & L141C & Helix $\alpha 4$ (domain I) & Increased capacity to form pores & Increased influx of ions & Slightly reduced & \\
\hline & $\mathrm{T} 142 \mathrm{C}$ & Helix $\alpha 4$ (domain I) & Highly reduced capacity to form pores & Extremely low influx of ions & Extremely reduced & \\
\hline & $\mathrm{A} 144 \mathrm{C}$ & Helix $\alpha 4$ (domain I) & Highly reduced capacity to form pores & Extremely low influx of ions & Extremely reduced & \\
\hline & $\mathrm{I} 145 \mathrm{C}$ & Helix $\alpha 4$ (domain I) & Reduced capacity to form pores & Low influx of ions & Slightly reduced & \\
\hline & $\mathrm{P} 146 \mathrm{C}$ & Helix $\alpha 4$ (domain I) & Reduced capacity to form pores & Low influx of ions & Extremely reduced & \\
\hline & L147C & Helix $\alpha 4$ (domain I) & Highly reduced capacity to form pores & Extremely low influx of ions & Extremely reduced & \\
\hline & $\mathrm{A} 149 \mathrm{C}$ & Helix $\alpha 4$ (domain I) & Increased capacity to form pores & Increased influx of ions & Slightly reduced & \\
\hline & R127E & Helix $\alpha 4$ (domain I) & Increased capacity to form pores & Increased influx of ions & Slightly reduced & \\
\hline & $\mathrm{R} 127 \mathrm{~N}$ & Helix $\alpha 4$ (domain I) & Increased capacity to form pores & Increased influx of ions & Slightly reduced & \\
\hline & $\mathrm{E} 128 \mathrm{C}$ & Helix $\alpha 4$ (domain I) & Highly reduced capacity to form pores & Extremely low influx of ions & Slightly reduced & \\
\hline & E129C & Helix $\alpha 4$ (domain I) & Abolished capacity to form pores & $\mathrm{n} / \mathrm{a}$ & Extremely reduced & \\
\hline & E129K & Helix $\alpha 4$ (domain I) & Abolished capacity to form pores & $\mathrm{n} / \mathrm{a}$ & Extremely reduced & \\
\hline & R131D & Helix $\alpha 4$ (domain I) & Increased capacity to form pores & Low influx of ions & Extremely reduced & \\
\hline & $\mathrm{R} 131 \mathrm{E}$ & Helix $\alpha 4$ (domain I) & Highly reduced capacity to form pores & Low influx of ions & Slightly reduced & \\
\hline & $\mathrm{R} 131 \mathrm{H}$ & Helix $\alpha 4$ (domain I) & Highly reduced capacity to form pores & Low influx of ions & Extremely reduced & \\
\hline
\end{tabular}


Table 1. Cont.

\begin{tabular}{|c|c|c|c|c|c|c|}
\hline Toxin & Mutation & Region & Characteristic & Molecular effect & Toxicity & Reference \\
\hline \multirow{7}{*}{ Cry1Aa } & R131Q & Helix $\alpha 4$ (domain I) & Highly reduced capacity to form pores & Extremely low influx of ions & Reduced & \multirow{6}{*}[67]{} \\
\hline & $\mathrm{D} 136 \mathrm{C}$ & Helix $\alpha 4$ (domain I) & Highly reduced capacity to form pores & Extremely low influx of ions & Extremely reduced & \\
\hline & $\mathrm{D} 136 \mathrm{~N}$ & Helix $\alpha 4$ (domain I) & Highly reduced capacity to form pores & Extremely low influx of ions & Extremely reduced & \\
\hline & $\mathrm{D} 136 \mathrm{Y}$ & Helix $\alpha 4$ (domain I) & Abolished capacity to form pores & $\mathrm{n} / \mathrm{a}$ & Extremely reduced & \\
\hline & $\mathrm{T} 142 \mathrm{D}$ & Helix $\alpha 4$ (domain I) & Abolished capacity to form pores & $\mathrm{n} / \mathrm{a}$ & Extremely reduced & \\
\hline & $\mathrm{T} 143 \mathrm{D}$ & Helix $\alpha 4$ (domain I) & Abolished capacity to form pores & $\mathrm{n} / \mathrm{a}$ & Extremely reduced & \\
\hline & Y445C & Loop 3 (domain II) & Reduced Bt-R175 binding capacity & $\mathrm{n} / \mathrm{a}$ & Extremely reduced & [57] \\
\hline \multirow{5}{*}{ Cry1Ab } & R99E & Helix $\alpha 3$ (domain I) & No oligomer formation & No membrane insertion & Extremely reduced & \multirow{5}{*}[68]{} \\
\hline & L100E & Helix $\alpha 3$ (domain I) & No significant alteration & No significant alteration & No significant alteration & \\
\hline & Y107E & Helix $\alpha 3$ (domain I) & No oligomer formation & No membrane insertion & Extremely reduced & \\
\hline & $\mathrm{I} 200 \mathrm{D}$ & Helix $\alpha 6$ (domain I) & No significant alteration & No significant alteration & No significant alteration & \\
\hline & Y203D & Helix $\alpha 6$ (domain I) & No significant alteration & No significant alteration & No significant alteration & \\
\hline \multirow{12}{*}{ Cry1Ab } & R99E & Helix $\alpha 3$ (domain I) & No oligomer formation & No membrane insertion & Reduced & \multirow{8}{*}[69]{} \\
\hline & E129K & Helix $\alpha 4$ (domain I) & Dominant negative effect & Low capacity to insert into cell membrane & Extremely reduced & \\
\hline & $\mathrm{N} 135 \mathrm{C}$ & Helix $\alpha 4$ (domain I) & Dominant negative effect & Low capacity to insert into cell membrane & Extremely reduced & \\
\hline & $\mathrm{D} 136 \mathrm{~N}$ & Helix $\alpha 4$ (domain I) & No competition with wild-type Cry1 Ab & Low capacity to insert into cell membrane & Slightly increased & \\
\hline & $\mathrm{A} 140 \mathrm{~K}$ & Helix $\alpha 4$ (domain I) & No competition with wild-type Cry1Ab & Low capacity to insert into cell membrane & Slightly increased & \\
\hline & $\mathrm{T} 142 \mathrm{C}$ & Helix $\alpha 4$ (domain I) & Dominant negative effect & Low capacity to insert into cell membrane & Extremely reduced & \\
\hline & $\mathrm{T} 143 \mathrm{D}$ & Helix $\alpha 4$ (domain I) & Dominant negative effect & Low capacity to insert into cell membrane & Extremely reduced & \\
\hline & $\begin{array}{c}\text { D136N, } \\
\text { T143D }\end{array}$ & Helix $\alpha 4$ (domain I) & Dominant negative effect & Low capacity to insert into cell membrane & Extremely reduced & \\
\hline & $\begin{array}{l}\text { E129K, } \\
\text { D136N }\end{array}$ & Helix $\alpha 4$ (domain I) & Dominant negative effect & Low capacity to insert into cell membrane & Extremely reduced & \multirow{4}{*}[71]{} \\
\hline & G439D & Loop 3 (domain II) & No binding to receptor & Low capacity to insert into cell membrane & No significant alteration & \\
\hline & $\mathrm{V} 171 \mathrm{C}$ & Helix $\alpha 5$ (domain I) & Reduced toxin folding & Increased capacity to insert into cell membrane & Highly increased & \\
\hline & $\mathrm{L} 157 \mathrm{C}$ & Helix $\alpha 5$ (domain I) & Reduced toxin folding & Increased capacity to insert into cell membrane & Increased & \\
\hline
\end{tabular}


Table 1. Cont.

\begin{tabular}{|c|c|c|c|c|c|c|}
\hline Toxin & Mutation & Region & Characteristic & Molecular effect & Toxicity & Reference \\
\hline \multirow{10}{*}{ Cry1Ab } & N372A & Loop 2 (domain II) & Increased biding capacity to BBMVs & $\mathrm{n} / \mathrm{a}$ & Highly increased & \multirow{4}{*}[58]{} \\
\hline & N372G & Loop 2 (domain II) & Increased biding capacity to BBMVs & $\mathrm{n} / \mathrm{a}$ & Highly increased & \\
\hline & N372del & Loop 2 (domain II) & Highly reduced binding capacity to BBMVs & $\mathrm{n} / \mathrm{a}$ & Extremely reduced & \\
\hline & $\begin{array}{c}\text { N372A, A282G, } \\
\text { L283S }\end{array}$ & Loop2, Loop $\alpha 8$ a, Loop $\alpha 8$ (domain II) & Increased biding capacity to BBMVs & $\mathrm{n} / \mathrm{a}$ & Highly increased & \\
\hline & Y153D & Loop between $\alpha 4$ and $\alpha 5$ (domain I) & Weaker membrane insertion & $\mathrm{n} / \mathrm{a}$ & Reduced & \multirow{6}{*}[12]{} \\
\hline & G282A, S283L & 8 Loop (domain II) & Reduced binding to receptor & $\mathrm{n} / \mathrm{a}$ & Highly reduced & \\
\hline & $\begin{array}{c}\text { R345A, Y350A, } \\
\text { Y351A }\end{array}$ & Loop 1 (Domain II) & Reduced binding to receptor & $\mathrm{n} / \mathrm{a}$ & Slightly reduced & \\
\hline & $\mathrm{I} 373 \mathrm{~A}$ & Loop 2 (Domain II) & Structure instability & $\mathrm{n} / \mathrm{a}$ & Reduced & \\
\hline & F371A, G374A & Loop 2 (Domain II) & Alters binding to membrane & $\begin{array}{l}\text { Increase in dissociation } \\
\text { from the membrane }\end{array}$ & Highly reduced & \\
\hline & F440A, G439A & Loop 3 (Domain II) & Affects binding to receptor & $\mathrm{n} / \mathrm{a}$ & Highly reduced & \\
\hline \multirow{10}{*}{ Cry1Ac } & N135Q & Helix $\alpha 4$ (domain I) & No oligomer formation & No membrane insertion & Extremely reduced & {$[70]$} \\
\hline & Q509A & GalNac binding site (domain III) & Highly reduced binding capacity to APN & $\mathrm{n} / \mathrm{a}$ & Slightly reduced & \multirow{3}{*}[72]{} \\
\hline & R511A & GalNac binding site (domain III) & Highly reduced binding capacity to APN & $\mathrm{n} / \mathrm{a}$ & Slightly reduced & \\
\hline & Y513A & GalNac binding site (domain III) & Highly reduced binding capacity to APN & $\mathrm{n} / \mathrm{a}$ & Slightly reduced & \\
\hline & Q509A & GalNac binding site (domain III) & No significant alteration & $\mathrm{n} / \mathrm{a}$ & Reduced & \multirow{5}{*}[73]{} \\
\hline & N510A & GalNac binding site (domain III) & Highly reduced binding capacity to ALP & $\mathrm{n} / \mathrm{a}$ & Reduced & \\
\hline & R511A & GalNac binding site (domain III) & No significant alteration & $\mathrm{n} / \mathrm{a}$ & Reduced & \\
\hline & Y513A & GalNac binding site (domain III) & Highly reduced binding capacity to ALP & $\mathrm{n} / \mathrm{a}$ & Extremely reduced & \\
\hline & W545A & GalNac binding site (domain III) & Highly reduced binding capacity to ALP & $\mathrm{n} / \mathrm{a}$ & Extremely reduced & \\
\hline & $\mathrm{T} 524 \mathrm{~N}$ & Loop $\beta 16-\beta 17$ (domain III) & $\mathrm{n} / \mathrm{a}$ & $\mathrm{n} / \mathrm{a}$ & Increased & {$[51]$} \\
\hline
\end{tabular}


The effect of glycosylation is extremely important for the activity of Cry1Ac toxins [74,75]. It is believed that the binding of loops 2 and 3 is dependent on a rapid and low-affinity interaction between a lectin-like region and $\mathrm{N}$-acetylgalactosamine (GalNac) molecules located in APN. The binding of Cry1Ac to Helicoverpa armigera has also been shown to be dependent on $N$-linked GalNac molecules [76]. Site-directed mutagenesis was performed on several Cry1Ac residues that form the GalNac binding site or that lie near it. Following alanine substitution, several mutants exhibited reduced binding capacity for APN or ALP, resulting in low M. sexta [72] and H. armigera larvae [73] mortality rates. The T524N Cry1Ac Domain III mutation resulted in a toxin with improved toxicity to Spodoptera exigua larvae that did not significantly differ in its effect against $H$. armigera larvae [51].

\subsection{Analyses of CrylIa12 and Its Variants Generated Using in Vitro Directed Evolution}

In recent years, the successful application of recombinant DNA technology using Bt toxins with activity for specific insect pests has been reported, resulting in many insect-resistant varieties from genetic engineering. Different genetically modified (GM) crops, including cotton, maize, potato, tomato, rice, eggplant, soybean and crucifer vegetables, expressing Cry toxins from Bt have been grown worldwide and are an effective tool for pest control.

Studies on insect pests of cotton plants to identify new Cry toxins led to the isolation of a Cry gene, whose toxin heterologously expressed in Escherichia coli exhibited toxicity against two insect pests, Anthonomus grandis and Spodoptera frugiperda [77]. This recombinant Cry1Ia12 protein at a concentration of $230 \mu \mathrm{g} / \mathrm{mL}$ resulted in $50 \%$ mortality of $A$. grandis larvae, whereas a concentration of only $5 \mu \mathrm{g} / \mathrm{mL}$ resulted in $50 \%$ mortality of $S$. frugiperda larvae [77]. In this study, the effect of the recombinant Cry1Ia12 toxin was compared with other Bt toxins, including Cry3Aa, Cry1Aa, Cry1Ac and Cry1Ba. However, none of these Cry toxins exhibited equivalent mortality rates for A. grandis as observed for Cry1Ia12 [77].

Although no adverse effects of Cry toxins have been described for humans, safety assessment guidelines have been established to ensure that any product developed from GM crops are safe for human consumption [78-81]. Furthermore, the development of a GM plant is not only time consuming but requires previous assurances regarding the toxicity and allergenicity of the introduced foreign proteins to ensure its safety for future commercialization. Therefore, in vivo assays using Cry1Ia12 have been performed in rats to assess its toxicity against mammals [81]. Studies using Wistar rats fed Cry1Ia12 toxin did not indicate any significant difference in total weight gain, protein digestibility or nitrogen balance in comparison to rats fed a diet without the Bt toxin. Moreover, no differences were observed in serum protein, albumin, urea nitrogen, alanine aminotransferase, aspartate aminotransferase and alkaline phosphatase levels. Even when Cry1Ia12 was administered as a single oral dose at a concentration of $12 \mathrm{mg} / \mathrm{animal}$, no toxicity was observed in the evaluated rats [81]. These results suggest the potential application of Cry1Ia12 toxin for the control of insect pests such as A. grandis and $S$. frugiperda.

Sugarcane giant borner Telchin licus licus (Lepidoptera: Castiniidae) is another important crop pest without an effective management for its control. Therefore, variants of Cry1Ia12 toxin targeting this insect pest have been generated using DNA shuffling and phage display techniques [13]. The Cry1Ia12 toxin exhibits considerable toxicity against the Lepidoptera fall armyworm (S. frugiperda) [77], and its 
potential for toxicity against another Lepidoptera species has been confirmed in a pioneering study in which a DNA shuffling-generated Cry1Ia variant exhibited toxicity to T. l. licus [13] (Figure 2). The nucleotide sequence of the original Cry1Ia12 gene was first chemically modified to accommodate plant codon usage. By selecting the clones with increased binding capacity against brush border membrane vesicles (BBMVs), thirty clones were selected for insecticidal activity against $T$. l. licus, of which four resulted in increased mortality of sugarcane giant borer larvae (Figure 2).

Figure 2. Mortality of T. l. licus following ingestion of Cry1Ia12 toxin and its variants (3 $\mu \mathrm{g}$ each). The results represent insect mortality after 5 days of a diet containing each of the respective proteins.

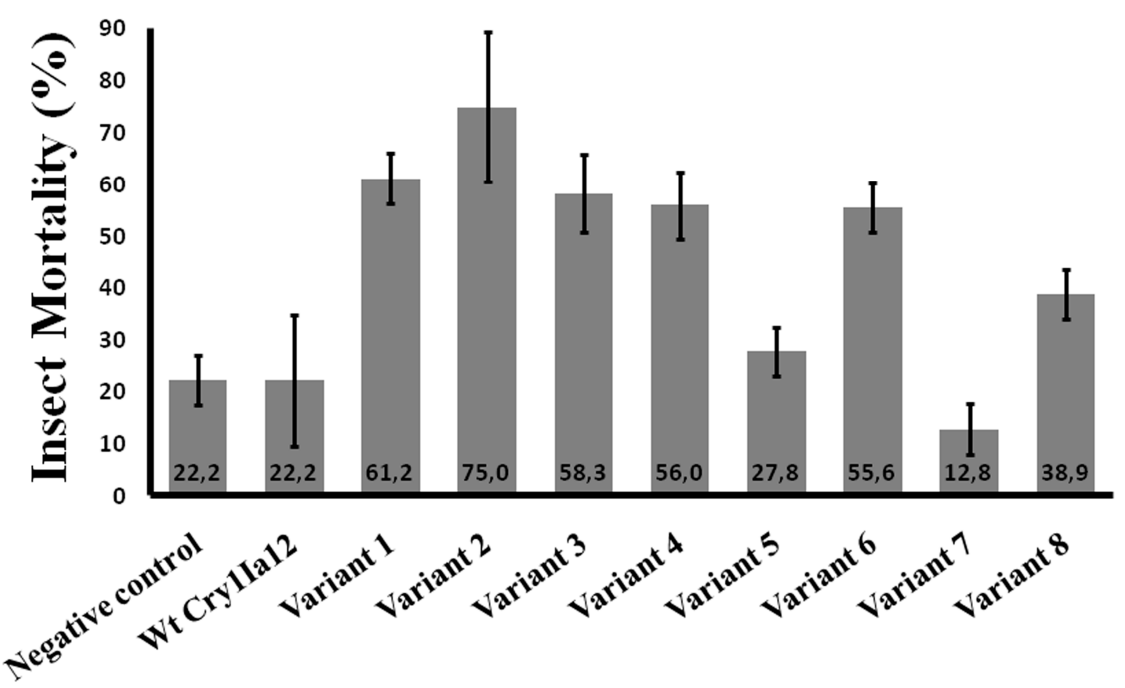

Table 2. Mutations present in Cry1Ia12 variants. Deletions are indicated by del and insertions by ins.

\begin{tabular}{cccc}
\hline Variant & Mutation & Domain & Reference \\
\hline $\mathbf{1}$ & D233N, E639G & I, III & {$[13]$} \\
\hline $\mathbf{2}$ & D233N & I & {$[13]$} \\
\hline $\mathbf{3}$ & I116T, L266F, K580R & I, I, III & {$[13]$} \\
\hline $\mathbf{4}$ & M45V & $N$-terminus(protoxin) & {$[13]$} \\
\hline $\mathbf{5}$ & D233N & I & This report \\
\hline & S84G, R159K, G380R & I, I, II & \\
& S84G & I & \\
\multirow{6}{*}{ R $159 \mathrm{~K}$} & I & This report \\
& L212del & I & \\
& S213del & I & \\
& Q413S & II & This report \\
\hline $\mathbf{7}$ & P414T & II & \\
& P419L & II & This report \\
& S84G & I & \\
\hline
\end{tabular}


Additional analysis identified six different mutations present in the selected Cry1Ia12 variants: D233N, E639G, I116T, L266F, K580R and M45V (Table 2) [13]. However, the D233N mutation (Figures 3 and 4) is present in three of the variants, and the authors concluded that this mutation was most likely responsible for $75 \%$ of the $T$. l. licus mortality level in bioassays, as shown for variant 2 (Figures 2 and 5) [13].

Figure 3. Tertiary structure of Cry1Ia12. $\alpha$-Helices colored red correspond to Domain I of the toxin. $\beta$-Sheets colored yellow color correspond to Domains II and III. Blue spheres represent the mutated residues from DNA shuffling involved in binding to receptors.

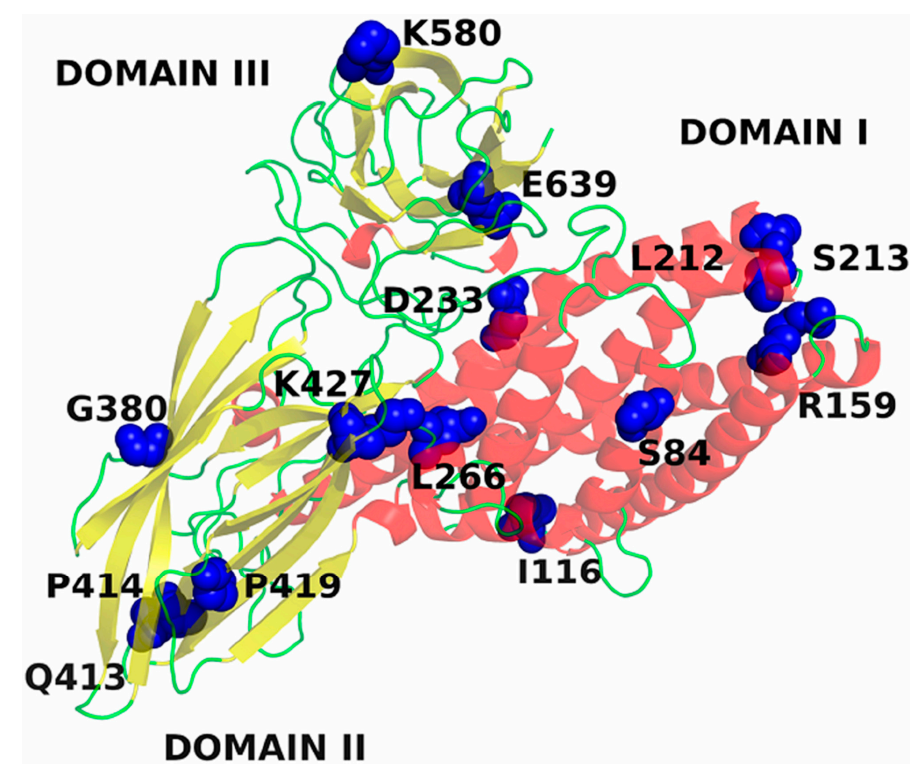

Figure 4. Alignment of 15 Cry toxins: Cry1Aa (AAP40639.1), Cry1Ab (AEV45790.1), Cry1Ac (ACC86135.1), Cry1Ia12 (ADB02877.1), Cry1F (ACD50893.1), Cry1Ba (AAK63251.1), Cry11Aa (YP_001573776.1), Cry8Ea1 (AAQ73470.1), Cry8Ka1 (ACQ99188.1), Cry3A (ABY49136.1), Cry9Ea (ADE60738.1), Cry2Ab (ACC86136.1), Cry4Aa (YP_001573833.1), Cry4Ba (YP_001573790.1) and Cry5Aa (Q45760.1). Polarity conserved residues in mutation regions are highlighted in gray, and residues mutated by DNA shuffling in Cry1Ia12 are depicted in bold red [13] and bold magenta (unpublished results). Deletions or additions of residues are further highlighted in black. Inserts A, B C, D, E, F, $\mathbf{G}$ and $\mathbf{H}$ correspond to different regions in the alignment.

A

cryseal

cry11aa

cry $2 a b$

cry5aa

cry4aa

cry 4 ba

cryokal

cry9ea

cry3a

crylf
crylac

crylab

crylaa

cry1ba

crylia12

mutations

\section{B}

cryseal

cryllaa

cry $2 a b$

crysaa

cry4aa

cry $4 b a$

cry $8 \mathrm{ka}$

crysea

cry3a

crylf

crylac

crylab

crylaa. $\begin{array}{lll}\text { GVPFAGQLAS--FYSFLVGELWPRG } & \text { crYlba } & \text { ITENARNTALARLQGLGDSFRAYQQSLEDWLENR---DDARTRSVLY } \\ \text { GVPFAGQVAS--LYSFILGELWPKG } & \text { crYlia12 } & \text { ISTYARNKALTDLKGLGDALAVYHDSLESWVGNR---NNTRARSVVR }\end{array}$ $\begin{array}{lll}\text { GVPFAGQLAS--EYSELVGELWPRG } & \text { crylba } & \text { ITENARNTALARLQGLGDSFRAYQQSLEDWLENR---DDARTRSVLY } \\ \text { GVPFAGQVAS--LYSFILGELWPKG } & \text { crY1ia12 } & \text { ISTYARNKALTDLKGLGDALAVYHDSLESWVGNR---NNTRARSVVR }\end{array}$

IAEYARAKALAELEGLGNNYQLYLTALEEWQENP---SSTRVLRDVR LSQDRVNILNAEYRGIIEVSDVFDA----YIKQP-----GETPATAK LNTDTLARVNAELTGLQANVEE FNRQVDNFL-NP---NRNAVPLSIT ITADEOTFLNGE I SGLONLAARYOSTMDDIOSHG---GENKVDSGLI IASTYISNANKILNR.SENVISTYHNHLKTWENNP----NPQNTQDVR VTAYVRTDANAKMTVVKDYLDQYTTKFNTWKREP---NNQSYRTAVI IEETVRNKALADLGNSGRALRSYLNAFEDWQKNP---NIFRSKELVK ISEOVVRNALDALTGIHDYYEEYLAALEEWLERP---SGARANLAFO

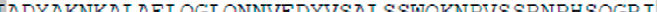
IETLERNRAITTLRGLADSYEVYLEALREWEENP---NNAQLREDVR IETLERNRAITTLRGLADSYEVYLEALREWEENR---NNAQLREDVR IEEFARNQAISRLEGLSNLYQIYAESFREWEADP---TNPALREEMR IEEFARNQAISRLEGLSNLYQIYAESFREWEA.DP---TNRALREEMR $\begin{array}{lll}\text { GVPFAGQLAS--FYSFLVGELWPRG } & \text { crYlba } & \text { ITENARNTALARLQGLGDSFRAYQQSLEDWLENR---DDARTRSVLY } \\ \text { GVPFAGQVAS--LYSFILGELWPKG } & \text { crYlia12 } & \text { ISTYARNKALTDLKGLGDALAVYHDSLESWVGNR---NNTRARSVVR }\end{array}$ $\begin{array}{lll}\text { GVPFAGQLAS--FYSFLVGELWPRG } & \text { crYlba } & \text { ITENARNTALARLQGLGDSFRAYQQSLEDWLENR---DDARTRSVLY } \\ \text { GVPFAGQVAS--LYSFILGELWPKG } & \text { crYlia12 } & \text { ISTYARNKALTDLKGLGDALAVYHDSLESWVGNR---NNTRARSVVR }\end{array}$ 75-GVPFAGQVAG--LYSEILGELWPKG-97 
Figure 4. Cont.

C
cry8eal
cry1laa
cry2ab
cry5aa
cry4aa
cry4ba
cry8ka1
cry9ea
cry3a
cry1f
crylac
crylab
crylaa
crylba
crylia12
mutations

E cry8eal
cry1laa
cry2ab
cry5aa
cry4aa
cry 4 ba
cry8ka1
cry9ea
cry3a
cry1f
crylac
crylab
crylaa
crylba
crylia12
mutations
-GEEWG----F--STTAINNYYNRQMSL IAQYSDHCVQWYRT -GSAWG----F--TQADVDSFIKLFNOKVLDYRTRLMRMYTE -A.DEWG----I--SAATLRTYRDYLKNYTRDYSNYCINTYQS -GPTWDSKINF--TPDAIDSFKTDIKNNIKLYSKTIYDVFQK NNRQFD----YLEPLPTA.IDYYPVLTKA IEDYTNYCVTTYKK -AQEWS----L--ARSAGDQLYNTMVQYTKEYIAHS ITWYNK -GKEWG----Y--TQADIDLFYREOVEFTKEYTEHCINIYND -GARWG---L--QQGQINLYFNAOODRTRIYTNHCVATYNR -GARWG----L--QQGQINLYFNAQQDRTRIYTNHCVATYNR
-GEEWG----Y--EKEDIAEFYKRQLKLTQEYTDHCVKWYNV -GQGWG----L--DIATVNNHYNRL INL IHRYTEHCLDTYNQ -GQRWG----F--DAATINSRYNDLTRL IGNYTDYAVRWYNT -GQRWG----F--DAATINSRYNDLTRLI GNYTDHAVRWYNT -GQRWG----F--DAATINSRYNDLTRLIGNYTDYAVRWYNT -GSEFG----L--TSQEIQRYYERQVERTRDYSDYCVEWYNT -GKEWG----L--SSSEISTFYNRQVERAGDYSDHCVKWYST 207-GKEWG------WSEISTFYNRQVERAGDYSNHCVKWYST-241 $\therefore$.

GGSI---QTQTYGTTSGS-SVIATQQIGE
GNEIMEVRTQTFYQNPNNEPIAPRDIINQ
GGIS---SGDI-GASPFN--------QNF
QDSV---ETRLYGQLPAV---DPQAGPNY
NISQ---KSSVFGNHNT---DKLKSLGL
SAMQ---ESGIYGSSGFG--SNLTHQIQL
GQAV---PN--YGDRTNP---VIVNRYNE
TSAV---QEDSYGQITNQ-----RTTINL
NDII---TSPFYGNKSE----PVQNLEF
GNPI---NEPIYGIFNPG---GAIWIADE
GPEF---TFPLYGTMGNA--TPQQRIVAQ
GPEF---TFPLYTMGNA--APQQRIVAQ
GPEF---AFPLFGNAGNA--APPV-LVSL
GGGL---NTSTHGATNTS--INPV-TLRF
GGTL---NISTQGSTNTS--INPV-TLPE
-GGTL---NISTQRSTNTS--INPV-TLPF-393

\section{$\mathbf{F}$}

crysea1 cry11aa cry $2 a b$ crysaa cry4aa cry $4 \mathrm{ba}$ cry $8 \mathrm{kal}$ cry9ea cry3a crylf crylac crylab crylaa crylba cry1ial2 mutations
D

WVEYNRFRREMTISVLDTMTTFP cryllaa cry $2 a b$ cry5aa cry $4 a a$

crytio

cry8ka1

crygea

cry3a

crylac

crylab

crylaa

crylba

crylial2

mutations GL---TFRNMCNLYVFPFAEAWS LHDMLEFRTYMF LNVEEYVSIWS FAKKQKYIEIMTTHCLDFARLFP WNTYNTYRTKMTTAVLDLVALFP WITENDYKREMT IQVLDI LALEA WIAFNRFRREMTLTVLDVVALFP WLNYHQFRREMTLMAMDLVALFP WVNENRYRREMTLTVLDLIALFB WSRFNQFRRELTLTVLDIVALEP WVRYNQERRELTLTVLDIVALEP WIRYNOFRRELTLTVLDIVSLFP WVRYNQFRRELTLTVLDIVALFS WVRYNQERRDLTLGVLDLVALFP WVRYNOFRRDMTLMVLDLVALFP 254-WVRYNQFRRDMTEMVLDLVALEP-276

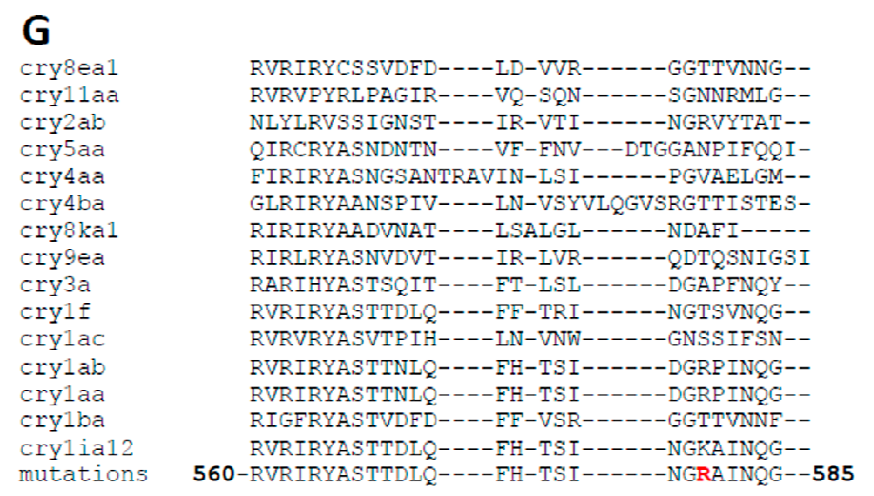

\begin{tabular}{|c|c|}
\hline crysea1 & RIELIPV-------- \\
\hline cryllaa & QLFLVKESAFTTQIN \\
\hline cry2ab & NIMLVPTN------- \\
\hline cry5aa & RIEFIP--ー------ \\
\hline cry4aa & KIEFLPI-------- \\
\hline cry $4 \mathrm{ba}$ & RIEIIPIT------- \\
\hline cry8ka1 & RIEFI PVDE------ \\
\hline crygea & SLEFIPV-ー-ー---- \\
\hline cry3a & KIEFIPV------- \\
\hline crylf & RIEFVPAEVT----- \\
\hline crylac & RFEEIPVTAT----- \\
\hline crylab & RIEFVPAEVT----- \\
\hline crylaa & RIEFVPAEVT----- \\
\hline crylba & KIEIIPVTAT----- \\
\hline cylia12 & RIEFVPVEV------ \\
\hline tations & 637-RIGEVPVEV------6 \\
\hline
\end{tabular}

To better understand the role of each amino acid substitution in the toxin structure and the consequences for receptor interactions, the amino acid sequences of 15 Cry toxins were aligned, six of which are classified as belonging to the Cryl family. The structural alignment indicated that all amino acid substitutions, with the exception of K580R, are conserved in all Cry1 toxins analyzed (Figure 4). Therefore, these regions may play an important role in stabilization of the protein structure, oligomerization, membrane insertion, receptor recognition or binding. A majority of the substitutions occurred in Domain I, which has been related to oligomerization and membrane insertion [82]. Dean and coworkers (1996) introduced amino acid substitutions into Cry1Ab toxins (Y153D, Y153A and Y153R) using site-directed mutagenesis. These authors concluded that the negatively charged aspartate is less favorable for membrane insertion in Cry1 A family toxins than positively charge residues, such as arginine, and non-polar residues, such as alanine. This report may also be applied to the D233N mutation identified in variant 2 (Cry1Ia12 toxin), as this protein contains only this mutation in its sequence and exhibited the highest increase in cytotoxicity among the selected variants. Hence, the 
structural implications of substituting an oxygen atom for a nitrogen atom in the tertiary toxin structure have been investigated. For D233 in wild-type Cry1Ia12 and N233 in variant 2, the respective side chains were found to be solvent exposed, and these residues lie close to $\beta$-strand 20 in Domain III [13]. The local charge difference caused by nitrogen substitution in variant 2 affected the interaction of D233 with the residues D598, Y599 and K600. Interestingly, the D233N mutation promoted the displacement of K600, which is solvent exposed in variant 2 (Figure 5). Whether K600 in the loop between $\beta 19$ and $\beta 20$ is involved in receptor recognition or membrane insertion remains unclear. D233 is conserved in Cryl toxins (Figure 5C), and the influence of asparagine substitution on Bt toxin binding to other Lepidoptera cadherin-like receptors is currently unknown. To address this question, studies on the corresponding residue in Cry1 Ab, D205, have been performed using in silico interaction models. Although preliminary, these results demonstrate the importance of D233 in the Cry1Ia12 mechanism of action and strongly indicate that this region is sensitive to point mutations, playing an important role in cytotoxicity. In addition, because D233 is located in $\alpha$-helix 6 in Domain I, it is known to be essential for toxin cell membrane insertion following receptor recognition and oligomerization [36]. If our conclusions are correct, it is likely that this mutation of a highly conserved negatively charged amino acid can improve or induce toxicity in other Cryl toxins, which have previously been shown to specifically bind BBMVs of target insects. Investigation of this approach in other insect orders may be valuable.

Figure 5. Detailed view of D233 from variant 2. (A) Distance between the NZ atom of K600 and OD2 of D233 (4.8 $\AA$ ) in wild-type Cry1Ia12; (B) ABPS-SEP of wild-type Cry1Ia12 depicting the proximity between K600, D598 and D233; (C) ABPS-SEP of variant 2 depicting the displacement of K600 from the salt bridge interaction with N233 and D598. The inset in the upper right corner represents the entire Cry1Ia12 structure.

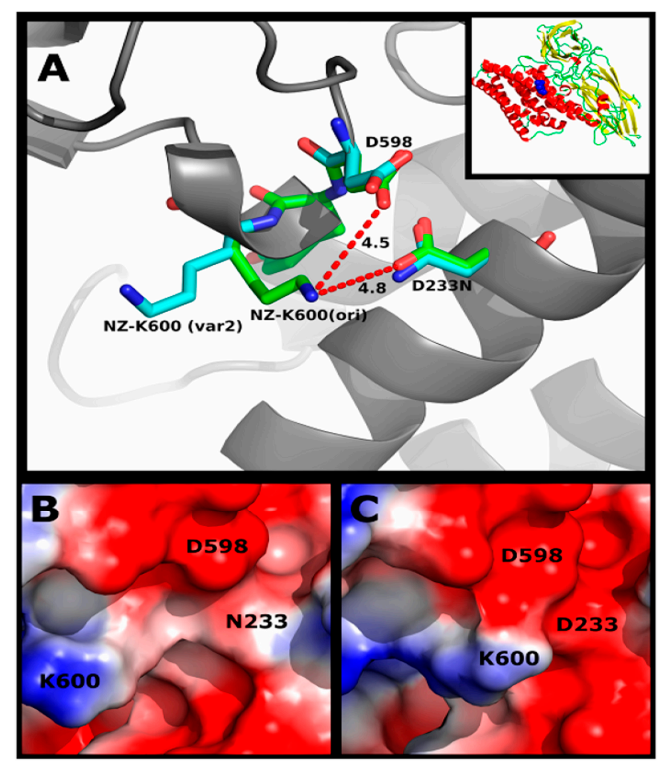

Variant 3 of Cry1Ia12 has also been investigated. Of the variants, only variant 3 lacks the D233N mutation and contains three unique substitutions: I116T, L266F and K580R [13]. The residue I116 is located in a solvent-exposed loop in Domain I of Cry1Ia12, and its neutral charge is well conserved among all 15 Cry toxins analyzed (Figure 4B). Although it is inserted in a solvent vulnerable region, 
I116 remains primarily oriented toward other hydrophobic residues in the toxin, such as M105, A120, P184 and L185 (Figure 6C,D). This observation suggests that mutation to a polar residue, such as threonine, may disturb the environment, exposing the residue toward the solvent and allowing additional intermolecular interactions. Due to the lack of accurate information regarding the mechanism by which Cry toxins form pores and insert in the membrane, the authors refrained from further discussion on the implications of this mutation on Cry1Ia12 cytotoxicity against $T$. l. licus. However, indirectly, Cry1 Ab A92 residue, which corresponds to A120 in Cry1Ia12, has been reported to be involved in membrane insertion [83] and is located in $\alpha$-helix 3, which has recently been reported to be directly involved in oligomer formation [84].

Figure 6. (A) Tertiary structure of Cry1Ia12. Domain I is colored red, whereas Domains II and III are colored yellow; (B) Detailed view of the interaction between L266 within the toxin and I60 in helix $\alpha-1$. Distances are shown as dashed lines and are measured in angstroms $(\AA)$. $\alpha$-Helix secondary structure is represented in red, and the protein surface is represented in green; $(C)$ Detailed view of I1 16 interactions with the hydrophobic residues M105, A120, P184 and L185 in Domain I. Distances are shown as dashed lines and measured in angstroms $(\AA)$. $\alpha$-Helices are colored red, and loops are colored green; (D) Tertiary structure of Cry1Ia12. Domain I is colored red, whereas Domains II and III are colored yellow.

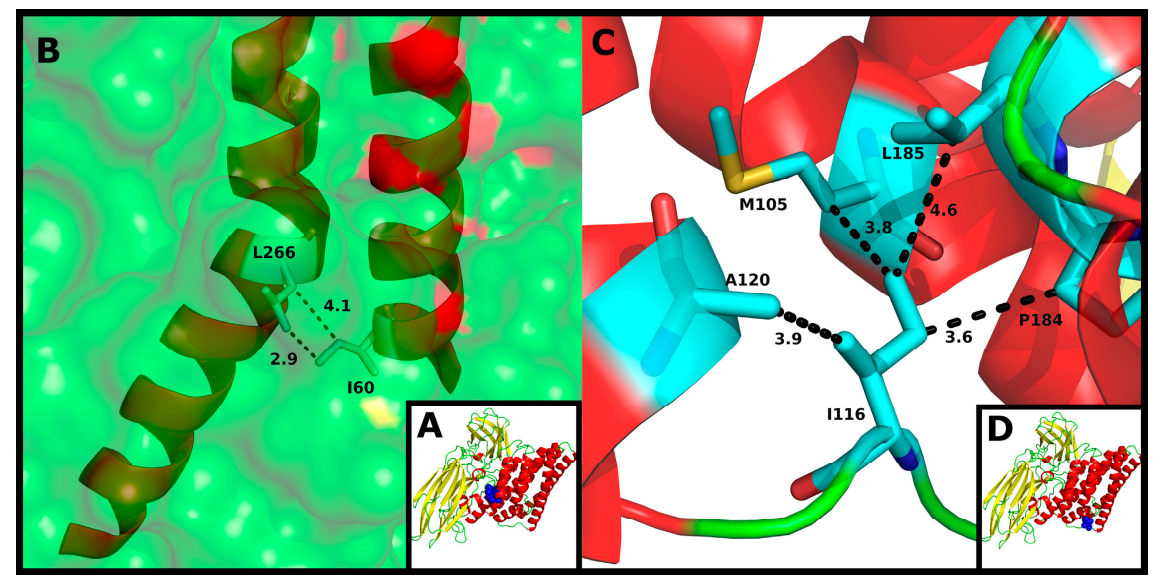

Regarding L266 (Figures 4D and 6B), this residue is buried inside the toxin and interacts, among other hydrophobic residues, with the N-terminal I60 residue in $\alpha$-helix 1 (Figure 6A,B). Cleavage of $\alpha$-helix 1 has been shown to induce oligomerization [56,85]. Although the L266F mutation may favor interaction with other hydrophobic residues, the aromatic side chain of phenylalanine is sufficiently large to sterically perturb the environment and displaces the surrounding residues. This feature may lead to a higher degree of freedom for $\alpha$-helix 1 and, consequently, facilitate its cleavage.

In addition, the K580R mutation (Figure 4G) is located in Domain III. This Domain has been associated with protection from proteolysis, receptor recognition and pore formation [86]. This residue is exposed and interacts with N578 (Cry1Ia12) in the loop between $\beta 18$ and $\beta 19$. In Cry1 Ac, N578 corresponds to N546 and has been reported to be important for BBMV binding in H. armigera [87]. Because both lysine and arginine are positively charged, any influence on receptor binding or cytotoxicity must be attributed to the larger size of the arginine side chain. 
Furthermore, other Cry1Ia12 variants have been generated using DNA shuffling and phage display, and the mutations were subsequently analyzed. Considering the variants that specifically interacted with T. l. licus BBMVs (data not shown), only one variant (variant 6, Table 2) resulted in an increase in the mortality rate during bioassays against $T$. l. licus larvae (Figure 2). Interestingly, this variant was the only one containing mutations in Loop 2 of Domain II (Q413S, P414T and P419L in Figure 4F), which has been related to receptor binding (this report) and has been extensively investigated. Nevertheless, Loop 2 apparently plays a key role in cytotoxicity [59] rather than binding. Hence, these observations support the importance of Loop 2 in cytotoxicity based on the interaction of this variant with T. l. licus BBMVs that was found to be similar to the interaction observed for wild-type Cry1Ia12 (data not shown). All other substitutions caused similar toxicity results compared to wild-type Cry1Ia12 and were excluded from additional analysis (Figure 2). Overall, these evaluations suggest that DNA shuffling contributes to the development of novel Bt toxins with higher toxicity against targeted insect pests. Moreover, the analyses indicated the participation of new regions that can help in the clarification of the mechanisms by which Bt toxins bind, oligomerize and insert into cell membranes to assess the validity of previously described functional models. Therefore, DNA shuffling strategies for the generation of novel molecules can be applied in the development of plant resistance against insect pests for biotechnological control, including resistance against the sugarcane giant borer.

\subsection{Use of Cry8 Toxins as a Strategic Tool against Coleopteran Insect Pests}

The utilization of shuffling and phage display techniques has also been applied to a Cry8Ka1 toxin, which exhibited activity against the cotton boll weevil in in vitro assays [88]. Previously, the cry8kal gene was isolated from a collection of B. thuringiensis of the Embrapa Genetic Resources and Biotechnology (Brasilia, Brazil) and used to generate novel mutated Bt toxins using DNA shuffling and phage display, as previously described. Hence, of $10^{5}$ variants produced after the fifth round of biopanning, thirty screened variants showed expression signals on dot blot assays and were selected for toxicity bioassays against $A$. grandis [14]. The variants Cry8Ka3 and Cry8Ka5 demonstrated a significant ability to reduce the survival of $A$. grandis larvae at concentrations of $2.83 \mu \mathrm{g} / \mathrm{mL}$ and $8.93 \mu \mathrm{g} / \mathrm{mL}$, respectively [14]. Analyses of the changes in the amino acid sequence indicated that modifications were distributed along all the Domains of the Cry8Ka5 protein compared with Cry8Ka1. One mutation was observed in Domain I, two mutations in Domain II and three mutations in Domain III of Cry8Ka5. Furthermore, one deletion was detected at the $N$-terminus of the protein, which resulted in a decrease in the size of Cry8Ka5 in comparison to Cry8Ka1. Although these modifications were observed in the variant protein, no changes were observed in the final structure. However, the mutations, particularly R271S, were essential for its toxicity against $A$. grandis [14].

Initial attempts to identify interacting receptors at the cell surface of insect pests were subsequently performed for Cry8Ka5. Ligand blot experiments were performed using one- and two-dimensional gel electrophoresis. Following de novo sequencing, two interacting proteins were identified: a heat-shock cognate protein (HSP) and a vacuolar ATPase (V-ATPase). These proteins have not been previously described as major Bt toxin interaction partners, in contrast to APNs and cadherins, and appear to play indirect roles in the toxicity of Cry $8 \mathrm{Ka} 5$ within the $A$. grandis midgut [88]. 
Recently, additional in silico analyses have been performed on the Cry8Ka5 structure to better understand its mechanism of action against insect pests. Hence, in comparison to the original toxin Cry8Ka1, the mutations in Cry8Ka5 are not located within conserved motifs between both proteins. Because these motifs are related to the structural stability of Cry toxins, it is suggested that both toxins demonstrate an identical global conformational behavior $[18,34,89]$.

Furthermore, a deletion of 16 residues at the $N$-terminus of Cry8Ka5 has been identified [35]. Nevertheless, this reduction in protein size did not affect Cry8Ka5 activity, as this deletion lies outside of the activation site of the Cry8Ka1 protoxin.

The mutation of an arginine to an asparagine residue at position 82 has been found in the middle portion of $\alpha$-helix 3 (Domain I) and near other residues involved in oligomerization and/or membrane insertion [66,67,71,82,90-93]. In Cry1A toxins, some arginine residues in $\alpha$-helix 3 participate in intramolecular salt bridges that contribute to the structural stability of Domain I [92]. However, in Cry8Ka1, the side chain of the solvent-exposed R82 lies in a position away from other potential salt bridge partners (aspartate and glutamate residues). This finding suggests that this residue interacts more strongly with the solvent. Cry8Ka5, whose toxicity is threefold higher than Cry8Ka1, contains a glutamine residue at position 82 , and the loss of a positively charged residue may interfere with membrane interaction or with oligomerization.

Moreover, other aromatic residues can commonly substitute tyrosine residues without compromising protein function [94]. In the case on Cry8ka5, the substitution Y260C is located in a long loop composed of 55 residues, which also contains $\alpha$-helix 8 and another smaller $\alpha$-helix. This variable region of Domain II is directly involved in Cry toxin specificity, as this region binds insect cadherin-like receptors $[34,95,96]$. Furthermore, this loop exhibits high flexibility, and $\alpha$-helix 8 exhibits the propensity to lose its secondary structure, as observed from molecular dynamics simulations. Although the substitution of Y260 with a cysteine residue did not result in an effective modification of the local electrostatic surface potential, the structural changes arising from different side chain topologies may influence intermolecular interactions, particularly those involving $\mathrm{Ca}^{2+}$ present in cadherins.

Generally, arginine and glycine can be involved in binding phosphate groups [97,98]. However, the glycine side chain confers higher flexibility to loops in comparison to arginine. The R508G mutation is located in a polymorphic region near $\beta$-sheet 18 , which is the fourth conserved region among Cry toxins [89]. This region is rich in arginine and tyrosine residues and has been reported to interact with GPI-APN and GPI-ALP in the presence (as in CrylAc) or absence of Gal-NAc (as in the Cry toxins studied in this report) [34,99]. Therefore, mutations in this loop may likely affect interactions with receptors and result in an increase in flexibility due to the presence of a glycine residue flanking $\beta$-sheet 18 at position 508. This feature can also facilitate the binding of the modified toxin (Cry8Ka5) with $A$. grandis membrane receptors.

The K538E mutation is located in a loop situated between $\beta$-sheets 20 and 21 of Domain III, which is exposed toward the solvent. This mutation promotes a substantial modification with the exchange of a positively charged residue with a negatively charged residue. In addition, in Cry8Ka1, K538 participates in a salt bridge with D520, which is located at the extreme loop of $\beta$-sheet 19 . However, in Cry8Ka5, the negative charge of glutamate (E538) in this region disrupts the interaction with D520 (Figure 7). In the loops of the three Domains, some residues have been characterized as important for 
Cry protein toxicity due to their involvement in the interaction with insect receptors $[72,87,99,100]$. Domain III is the smallest of the three Domains and has been reported to function as a receptor binding site for GPI-ALP, GPI-APN [41,65] and Gal-NAc [31]. Therefore, the K538E mutation may modify the affinity for GPI-anchored proteins from $A$. grandis and may contribute to the enhanced toxicity of Cry8Ka5, which has been previously inferred from bioassays.

Figure 7. The tertiary structure of Cry8Ka5. Roman numbers indicate the Domains of the Cry toxin. Mutated residues (R82Q, R508G, and K538E) observed in the three Domains are shown in a detailed view.

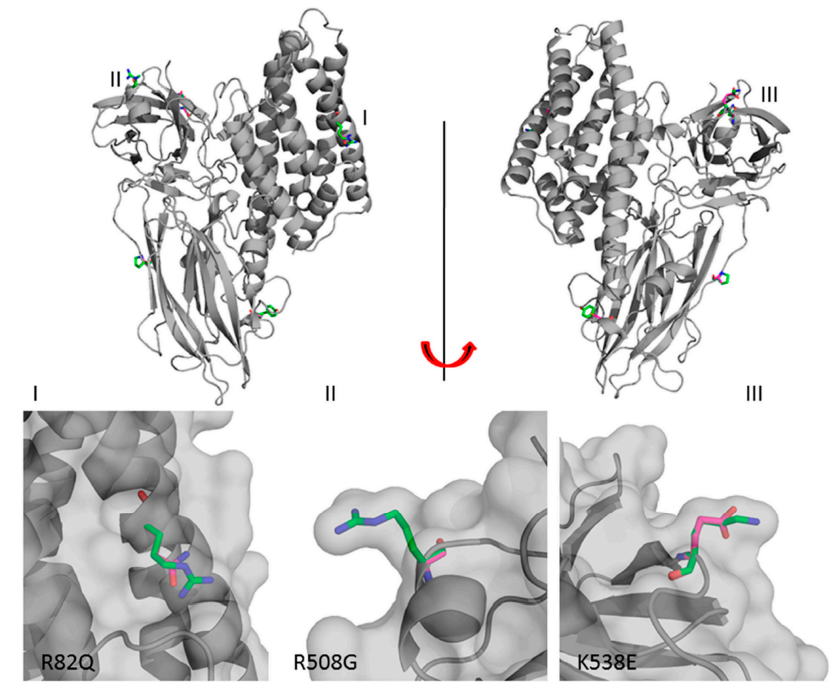

Although precise structural characterization of the interactions between Cry toxins and Coleopteran membrane receptors is lacking, using the details reported for Lepidoptera and Diptera receptors, it is possible to identify the regions of Cry8Ka5 that confer toxicity from previous results reported for the CrylA and Cry3Aa toxins. From these details, it is possible to estimate the contribution of the previously described mutations to insect cell toxicity.

\section{Perspectives of Biotechnological Application of Novel Molecules Selected by in Vitro Directed Evolution for Insect Pest Control}

Currently, over 60 commercially approved for market worldwide transgenic events have been developed to provide resistance against several insect pest species. Of these transgenic events, 41 contain toxins from the Cry1A family (Table 3). In contrast, events containing proteins from the Cry1I or Cry8 families have not yet been reported [101]. Lepidoptera insects are the primary target for all transgenic plants to date, with only six events exhibiting resistance against Coleopteran pests, which are restricted to the Diabrotica species and have been exclusively developed for maize plants. The first transgenic plants released to the market have already lost their effectiveness due to the development of insect resistance to Cry toxins present in transformed plants over the last 20 years. Therefore, new toxins have been inserted into plant species to restore their ability to control pest growth. Hence, events with two or more Cry toxins serve different purposes: (i) to decrease the rate of insect development of evolutionary features that inhibit Cry toxin activity for pest control (plant pyramid) and (ii) to increase plant resistance against different insect species at once. 
Table 3. Transgenic plants expressing toxins from Cry1A family for insect resistance. Source: [102].

\begin{tabular}{|c|c|c|c|c|c|}
\hline Plant & Company & Event & Year/Country regulatory approval & Toxin(s) inserted & Insect species for resistance \\
\hline \multirow[t]{2}{*}{ Soybean } & \multirow[t]{2}{*}{ Monsanto Company } & MON87701 & Canada (2010); United States (2011) & Cry1Ac & $\begin{array}{l}\text { Anticarsia gemmatalis, } \\
\text { Pseudoplusia includens }\end{array}$ \\
\hline & & MON87701/MON89788 & Colombia (2012) & Cry1Ac, CP4 epsps & Lepidopteran pests \\
\hline \multirow{11}{*}{ Cotton } & Dow AgroSciences LLC & $3006-210-23$ & $\begin{array}{l}\text { Mexico (2004); United States (2004); } \\
\text { Canada, Japan (2005) }\end{array}$ & Cry1Ac & $\begin{array}{l}\text { Heliothis virescens, Helicoverpa zea, } \\
\text { Pectinophora gossypiella, } \\
\text { Spodoptera exigua }\end{array}$ \\
\hline & Calgene Inc. & $31807 / 31808$ & United States (1997/1998); Canada, Japan (1998/1999) & Cry1Ac & Lepidopteran pests \\
\hline & Syngenta Seeds, Inc. & COT67B & Australia, United States (2009) & Cry $1 \mathrm{Ab}$ & Helicoverpa zea, Heliothis virescens \\
\hline & \multirow{3}{*}{ Dow AgroSciences LLC } & DAS-21Ø23-5/DAS-24236-5 & $\begin{array}{l}\text { Mexico, United States (2004); Australia (2005); } \\
\text { Japan (2005); Korea (2005/2008); Brazil (2009) }\end{array}$ & Cry1Ac, Cry1F & $\begin{array}{l}\text { Helicoverpa zea, Heliothis virescens, } \\
\text { Pectinophora gossypiella }\end{array}$ \\
\hline & & $\begin{array}{l}\text { DAS-21Ø23-5/DAS-24236-5/ } \\
\text { MON-Ø1445-2 }\end{array}$ & Mexico (2005); Korea (2006); Japan (2006) & Cry1Ac, Cry1F & $\begin{array}{l}\text { Helicoverpa zea, Heliothis virescens, } \\
\text { Pectinophora gossypiella }\end{array}$ \\
\hline & & $\begin{array}{l}\text { DAS-21Ø23-5/DAS-24236-5/ } \\
\text { MON88913 }\end{array}$ & Japan, Korea, Mexico (2006) & Cry 1 Ac, Cry1F & $\begin{array}{l}\text { Helicoverpa zea, Heliothis virescens, } \\
\text { Pectinophora gossypiella }\end{array}$ \\
\hline & $\begin{array}{l}\text { JK Agri Genetics LTd } \\
\text { (India) }\end{array}$ & Event-1 & India (2006) & Cry1Ac & $\begin{array}{l}\text { Earias vittella, Helicoverpa armigera, } \\
\text { Pectinophora gossypiella }\end{array}$ \\
\hline & Bayer CropScience & LLCotton25/MON15985 & Japan (2006/2007); Korea (2007/2008); Mexico (2008) & Cry1Ac, Cry2Ab & $\begin{array}{l}\text { Helicoverpa zea, Heliothis virescens, } \\
\text { Pectinophora gossypiella }\end{array}$ \\
\hline & \multirow{3}{*}{ Monsanto Company } & MON15985 & $\begin{array}{l}\text { Australia, United States (2002); Japan (2002/2003); } \\
\text { Canada, Mexico, Philippines, South Africa (2003); } \\
\text { Korea (2003/2004) European Union (2005); China, India } \\
\text { (2006); Burkina Faso (2008); Brazil, Colombia (2009) }\end{array}$ & Cry1Ac, Cry2Ab2 & $\begin{array}{l}\text { Helicoverpa zea, Heliothis virescens, } \\
\text { Pectinophora gossypiella }\end{array}$ \\
\hline & & MON-15985-7/MON-Ø1445-2 & $\begin{array}{l}\text { Australia (2002); Korea (2004/2008); Philippines (2004); } \\
\text { European Union, Japan (2005); Mexico (2006) }\end{array}$ & Cry1Ac, Cry2Ab & $\begin{array}{l}\text { Helicoverpa zea, Heliothis virescens, } \\
\text { Pectinophora gossypiella }\end{array}$ \\
\hline & & MON-ØØ531-6/MON-Ø1445-2 & $\begin{array}{l}\text { Mexico (2002); Australia (2003); Japan, Philippines } \\
\text { (2004); Korea (2004/2008); European Union, } \\
\text { South Africa (2005); Colombia (2008); } \\
\text { Argentina, Brazil (2009) }\end{array}$ & Cry1Ac & $\begin{array}{l}\text { Helicoverpa zea, Heliothis virescens, } \\
\text { Pectinophora gossypiella }\end{array}$ \\
\hline
\end{tabular}


Table 3. Cont.

\begin{tabular}{|c|c|c|c|c|c|}
\hline Plant & Company & Event & Year/Country regulatory approval & Toxin(s) inserted & Insect species for resistance \\
\hline \multirow[b]{2}{*}{ Cotton } & \multirow[b]{2}{*}{ Monsanto Company } & MON15985/MON88913 & $\begin{array}{l}\text { Japan (2005/2006); Australia, Mexico, Philippines (2006); } \\
\text { Korea (2006/2008); South Africa (2007); Colombia (2010) }\end{array}$ & Cry1Ac, Cry2Ab & $\begin{array}{l}\text { Helicoverpa zea, } \\
\text { Heliothis virescens, } \\
\text { Pectinophora gossypiella }\end{array}$ \\
\hline & & MON531/757/1076 & $\begin{array}{l}\text { United States (1995); Australia, Canada (1996); } \\
\text { Japan, Mexico, South Africa (1997); Argentina (1998); India (2002); } \\
\text { Colombia (2003); Korea (2003/2004); China, Philippines (2004); } \\
\text { Brazil, European Union (2005) }\end{array}$ & CrylAc & $\begin{array}{l}\text { Helicoverpa zea, } \\
\text { Heliothis virescens, } \\
\text { Pectinophora gossypiella }\end{array}$ \\
\hline Tomato & Monsanto Company & 5345 & United States (1998); Canada (2000) & Cry1Ac & $\begin{array}{l}\text { Helicoverpa zea, } \\
\text { Heliothis virescens, } \\
\text { Pectinophora gossypiella }\end{array}$ \\
\hline \multirow{5}{*}{ Maize } & \multirow{5}{*}{ Syngenta Seeds, Inc. } & 176 & $\begin{array}{l}\text { United States (1995); Canada (1995/1996); Japan (1996); } \\
\text { Argentina (1996/1998); European Union, The Netherlands, } \\
\text { Switzerland, United Kingdom (1997); Australia, South Africa (2001); } \\
\text { Philippines (2003); Korea (2003/2006); China, Taiwan (2004) }\end{array}$ & Cry1Ab & Ostrinia nubilalis \\
\hline & & $\begin{array}{l}\text { BT11 (X4334CBR, } \\
\text { X4734CBR) }\end{array}$ & $\begin{array}{l}\text { Canada, Japan, United States (1996); European Union, Switzerland, } \\
\text { United Kingdom (1998); Argentina, Australia (2001); South Africa (2002); } \\
\text { Korea (2003/2006); Russia (2003); China, Taiwan, Uruguay (2004); } \\
\text { Philippines (2005); Brazil, Mexico (2007); Colombia (2008/2009) }\end{array}$ & Cry $1 \mathrm{Ab}$ & Ostrinia nubilalis \\
\hline & & BT11/GA21 & $\begin{array}{l}\text { Canada (2005); Korea (2006/2008); Japan, Mexico, Philippines (2007); } \\
\text { Argentina, Brazil (2009); Uruguay (2011); Colombia (2012) }\end{array}$ & $\begin{array}{l}\text { Cry } 1 \mathrm{Ab}, \\
\text { Vip3Aa20 }\end{array}$ & $\begin{array}{l}\text { Agrotis ipsilon, Ostrinia nubilalis, } \\
\text { Helicoverpa zea, } \\
\text { Spodoptera frugiperda }\end{array}$ \\
\hline & & BTT11/GA21/MIR162 & Brazil (2011); Colombia (2012) & $\begin{array}{l}\text { Cry1Ab, } \\
\text { Vip3Aa20 }\end{array}$ & $\begin{array}{l}\text { Helicoverpa zea, } \\
\text { Spodoptera frugiperda, } \\
\text { Agrotis ipsilon }\end{array}$ \\
\hline & & BT11/MR162 & United States (2009) & $\begin{array}{l}\text { Cry1Ab, } \\
\text { Vip3Aa20 }\end{array}$ & $\begin{array}{l}\text { Agrotis ipsilon, Ostrinia nubilalis, } \\
\text { Helicoverpa zea, } \\
\text { Spodoptera frugiperda, } \\
\text { Spodoptera albicosta }\end{array}$ \\
\hline
\end{tabular}


Table 3. Cont.

\begin{tabular}{|c|c|c|c|c|c|}
\hline Plant & Company & Event & Year/Country regulatory approval & Toxin(s) inserted & Insect species for resistance \\
\hline \multirow{12}{*}{ Maize } & \multirow{4}{*}{ Syngenta Seeds, Inc. } & BT11/MIR162/MIR604 & United States (2009) & Cry1Ab, Vip3Aa20 & $\begin{array}{l}\text { Ostrinia nubilalis, Diatraea crambidoides, } \\
\text { Spodoptera frugiperda, Pseudaletia unipunctata, } \\
\text { Spodoptera exigua, Agrotis ipsilon, } \\
\text { Striacosta albicosta, Diatraea saccharalis, } \\
\text { Diabrotica virgiferaDiabrotica barberi, } \\
\text { Papaipema nebris }\end{array}$ \\
\hline & & BT11/MIR162/MIR604/GA21 & Colombia (2012) & $\begin{array}{c}\text { Cry1Ab, } \\
\text { mCry3A,Vip3a20 }\end{array}$ & $\begin{array}{l}\text { Diabrotica spp., Helicoverpa zea, } \\
\text { Ostrinia nubilalis, Spodoptera frugiperda, } \\
\text { Agrotis ipsilon }\end{array}$ \\
\hline & & BT11/MIR604 & $\begin{array}{l}\text { Canada, Japan, Korea, Mexico, Philippines (2007); } \\
\text { Colombia (2012) }\end{array}$ & Cry $1 \mathrm{Ab}, \mathrm{mCry} 3 \mathrm{~A}$ & Diabrotica spp., Ostrinia nubilalis \\
\hline & & BT11/MIR604/GA21 & Canada, Japan (2007); Korea, Mexico, Philippines (2008); & Cry1Ab & Diabrotica spp, Ostrinia nubilalis \\
\hline & $\begin{array}{l}\text { DeKalb Genetics } \\
\text { Corporation }\end{array}$ & DBT418 & $\begin{array}{l}\text { Canada, United States (1997); Japan (1999); } \\
\text { Australia (2002); Philippines, Taiwan (2003); } \\
\text { Korea (2004) }\end{array}$ & Cry1Ac & Ostrinia nubilalis \\
\hline & \multirow{7}{*}{ Monsanto Company } & GA21/MON810 & $\begin{array}{l}\text { Japan, South Africa (2003); Korea, Philippines (2004); } \\
\text { European Union (2005) }\end{array}$ & Cry $1 \mathrm{Ab}$ & Ostrinia nubilalis, Other Lepidoteran pests \\
\hline & & MON80100 & United States (1996) & Cry1Ab & Ostrinia nubilalis \\
\hline & & MON802 & United States (1996/1997); Canada, Japan (1997) & Cry1 Ab & Ostrinia nubilalis \\
\hline & & MON809 & Canada, United States (1996); Japan (1997/1998) & Cry1Ab & Ostrinia nubilalis \\
\hline & & MON810 & $\begin{array}{l}\text { United States (1995/1996); Japan (1996/1997); } \\
\text { Canada, South Africa (1997); Argentina, } \\
\text { European Union (1998); Australia, Switzerland (2000); } \\
\text { Mexico, Philippines, Taiwan (2002); Korea (2002/2004); } \\
\text { Colombia, Uruguay (2003); China (2004); Brazil (2007) }\end{array}$ & Cry $1 \mathrm{Ab}$ & Ostrinia nubilalis \\
\hline & & MON810/LY038 & Philippines (2006); Japan (2007) & Cry1Ab & Ostrinia nubilalis \\
\hline & & MON810/MON88017 & $\begin{array}{l}\text { Japan (2005); Canada, Korea, Mexico (2006); } \\
\text { Taiwan (2009); Colombia (2011) }\end{array}$ & Cry1Ab, Cry3Bb1 & Ostrinia nubilalis, Diabrotica virgifera \\
\hline
\end{tabular}


Table 3. Cont.

\begin{tabular}{|c|c|c|c|c|c|}
\hline Plant & Company & Event & Year/Country regulatory approval & Toxin(s) inserted & Insect species for resistance \\
\hline \multirow{9}{*}{ Maize } & \multirow{4}{*}{ Monsanto Company } & MON863/MON810 & $\begin{array}{l}\text { Japan, Korea, Philippines (2004); European Union (2005); } \\
\text { Mexico (2006) }\end{array}$ & Cry $1 \mathrm{Ab}, \mathrm{Cry} 3 \mathrm{Bb} 1$ & Ostrinia nubilalis, Diabrotica sp. \\
\hline & & MON863/MON810/NK603 & $\begin{array}{l}\text { Canada, Japan, Korea (2004); Philippines (2004/2005); } \\
\text { Mexico (2006); Taiwan (2009) }\end{array}$ & Cry $1 \mathrm{Ab}, \mathrm{Cry} 3 \mathrm{Bb} 1$ & Ostrinia nubilalis, Diabrotica virgifera \\
\hline & & MON89034 & $\begin{array}{l}\text { Japan, United States (2007/2008); } \\
\text { Australia, Canada, Taiwan (2008); Brazil, European Union, } \\
\text { Korea, Philippines (2009); Colombia (2010) }\end{array}$ & Cry1A.105,Cry2Ab & Ostrinia sp., Diabrotica sp. \\
\hline & & MON89034/MON88017 & $\begin{array}{l}\text { Japan (2008); Korea, Philippines, Taiwan (2009); } \\
\text { Argentina (2010); Colombia (2011) }\end{array}$ & $\begin{array}{l}\text { Cry1A.105,Cry2Ab, } \\
\text { Cry3Bb1 }\end{array}$ & $\begin{array}{l}\text { Diabrotica virgifera, } \\
\text { Lepidopteran pests }\end{array}$ \\
\hline & $\begin{array}{l}\text { Monsanto Company } \\
\text { and Mycogen Seeds c/o } \\
\text { Dow LLC }\end{array}$ & $\begin{array}{c}\text { MON89034/TC1507/ } \\
\text { MON88017/DAS-59122-7 }\end{array}$ & $\begin{array}{l}\text { Canada, Japan, Korea, Taiwan, United States (2009); } \\
\text { Colombia, Mexico, Philippines (2010) }\end{array}$ & $\begin{array}{l}\text { Cry1A.105, Cry1Fa2, } \\
\text { Cry2Ab, } \\
\text { Cry3Bb1,Cry34Ab1, } \\
\text { Cry35Ab1 }\end{array}$ & $\begin{array}{l}\text { Ostrinia nubilalis, Helicoverpa zea, } \\
\text { Spodoptera frugiperda, Agrotis ipsilon }\end{array}$ \\
\hline & Monsanto Company & NK603/MON810 & $\begin{array}{l}\text { Canada (2001); Japan, Korea, Mexico, Philippines (2004); } \\
\text { Argentina (2005/2007); European Union (2007); } \\
\text { Taiwan, Brazil, Colombia, El Salvador (2009); } \\
\text { Uruguay (2011) }\end{array}$ & Cry $1 \mathrm{Ab}$ & Ostrinia nubilalis, Lepidopteran pests \\
\hline & $\begin{array}{c}\text { Bayer CropScience } \\
\text { (Aventis CropScience } \\
\text { (AgrEvo)) }\end{array}$ & T25/MON810 & Japan (2003); Colombia (2012) & CrylAb & Ostrinia nubilalis, Lepidopteran pests \\
\hline & \multirow{2}{*}{ DuPont Pioneer } & TC1507/MON810 & Brazil (2011); Colombia (2012); Argentina (2013) & Cry $1 \mathrm{Ab}, \mathrm{Cry} 1 \mathrm{Fa} 2$ & Lepidopteran pests \\
\hline & & TC1507/MON810/NK603 & Canada (2011); Colombia (2012); Argentina (2013) & Cry $1 \mathrm{Ab}$, Cry1Fa2 & Lepidopteran pests \\
\hline
\end{tabular}


Nevertheless, one successful approach for plant resistance against targeted pests, as well as to retard insect resistance toward Cry toxins, is the use of proteins with specific mutated sites. Whether these mutations are selected from DNA shuffling or in silico analyses, Cry toxin mutants are innovative and efficient tools that can be applied to transformed plants for insect control.

The purpose of using molecular evolution techniques, such as DNA shuffling and in silico analyses is to copy the natural design procedures and accelerate them using in vitro direct selection methodologies for a single goal. It is already known that complex linear sequences can rapidly pass through evolution by recombination between individuals, whether it includes high or low levels of point mutagenesis [16,102]. Thus, the use of improved phage display selection of DNA-shuffled libraries, together with in silico analyses, has been innovative, and these techniques represent potentially effective tools for the development of new molecules with increased activity against insect pests. The application of mutant Cry toxins for plant transformation and acquisition of different cultivars expressing these foreign proteins present three major advantages (in comparison to the use of insecticide molecules extracted from natural resources): (i) the ability to use only one molecule with enhanced activity against insect pests or a molecule that shares features from two different molecules; (ii) knowledge of the specific location of mutations present in the novel protein facilitates the study and verification of its effects against insect pest receptors, as well as its mechanism of action in the targeted cells; and (iii) the exposure of a mutated molecule can retard the development of resistance and coevolution by insect pests.

Therefore, proteins from other Cry families, such as Cry1I and Cry8, are potential molecules for the development of plant species resistant to other insect pests, such as Coleopterans and the sugarcane giant borer. In conclusion, the use of combined DNA shuffling and in silico evaluations can accelerate the design of point mutations, which will allow directed evolution of targeted molecules for biocontrol in agribusiness. Beyond biotechnological applications, these techniques will contribute to a decrease in the use of chemical pesticides in agriculture, consequently leading to a significant enhancement in crop production, as well as facilitate an understanding of the mechanism of action of Cry toxins, which may reveal new insights into the technological development of pest control.

\section{Acknowledgments}

The authors are thankful for the financial support of Brazilian agencies CAPES, CNPq, FAP-DF and EMBRAPA.

\section{Author Contributions}

Authors Wagner A. Lucena and Patrícia B. Pelegrini contributed equally with writing, edition and organization of the manuscript. Diogo Martins de Sá contributed with in silico assays of mutants from Cry1Ia12 and Cry8Ka5. Fernando C. A. Fonseca contributed with literature revision and writing about Cry1A toxins and its mutants, as well as with the design of in silico structures related to this group of proteins. Jose E. Gomes Jr. and Maria Cristina M. da Silva contributed equally with Phage Display and shuffling assays performed with the described Cry toxins, as well as with in vitro bioassays related to Cry1Ia12. Leonardo L. P. de Macedo and Raquel Sampaio contributed with in vivo bioassays related to 
Cry8Ka mutants. Maria Fátima Grossi de Sá contributed with the supervision of all experiments described in the manuscript, as well as with the final edition of the article.

\section{Abbreviations}

$\mathrm{LC}_{50}$ - the concentration of toxins used to present $50 \%$ of its total insecticide activity.

\section{Conflicts of Interest}

The authors declare no conflict of interests.

\section{References}

1. Gilliand, A.; Chambers, C.; Bones, E.; Ellar, D. Role of Bacillus thuringiensis Cry1 d-endotoxin binding in determining potency during Lepidopteran Larval development. Appl. Environ. Microbiol. 2002, 68, 1509-1515.

2. Zhang, X.; Candas, M.; Griko, N.B.; Taussig, R.; Bulla, L.A., Jr. A mechanism of cell death involving an adenylyl cyclase/PKA signaling pathway is induced by the CrylAb toxin of Bacillus thuringiensis. Proc. Natl. Acad. Sci. USA 2006, 103, 9897-9902.

3. Bravo, A.; Gill, S.; Soberón, M. Mode of action of Bacillus thuringiensis Cry and Cyt and their potential for insect control. Toxicon 2007, 49, 423-435.

4. Li, J.; Carroll, J.; Ellar, D. Crystal structure of insecticidal $d$-endotoxin from Bacillus thuringiensis at 2.5A resolution. Nature (London) 1991, 353, 815-821.

5. Grochulski, P.; Masson, L.; Borisova, S.; Pusztai-Carey, M.; Schwartz, J. Cry1A(a) insecticidal toxin: crystal structure and channel formation. J. Mol. Biol. 1995, 254, 447-464.

6. Derbyshire, D.; Ellar, D.; Li, J. Crystallization of the Bacillus thuringiensis toxin Cry1Ac and its complex with the receptor ligand $N$-acetyl-D-galactosamine. Acta Crystallogr. Sect. D 2001, 57, 1938-1944.

7. Galitsky, N.; Cody, V.; Wojtczak, A.; Ghosh, F.; Luft, J.; Pangborn, W.; English, L. Structure of the insecticidal bacterial $\delta$-endotoxin Cry3Bb1 of Bacillus thuringiensis.Acta Crystallogr. Sect. D 2001, 57, 1101-1109.

8. Morse, R.; Yamamoto, T.; Stud, R. Structure of Cry2Aa suggests an unexpected receptor binding epitope. Structure 2001, 9, 409-417.

9. Boonserm, P.; Davis, P.; Ellar, D.; Li, J. Crystal structure of the mosquito-larvicidal toxin Cry4Ba and its biological implications. J. Mol. Biol. 2005, 348, 363.

10. Guo, S.; Ye, S.; Liu, Y.; Wei, L.; Xue, J. Crystal structure of Bacillus thuringiensis Cry8Ea1: An insecticidal toxin toxic to underground pests, the larvae of Holotrichia parallela. J. Struct. Biol. 2009, 168, 259-266.

11. Hui, F.; Scheib, U.; Hu, Y.; Sommer, R.J.; Aroian, R.V.; Ghosh, P. Structure and glycolipid properties of the nematicidal protein Cry5B. Biochemistry. 2012, 51, 9911-9921.

12. Dean, D.; Rajamohan, F.; Lee, M.; Wu, S.-J.; Chen, X.-J.; Alcantara, E.; Hussain, S. Probing the mechanism of action of Bacillus thuringiensis insecticidal proteins by site-directed mutagenesis-A minireview. Gene 1996, 179, 111-117. 
13. Craveiro, K.I.C.; Gomes Junior, J.E.; Silva, M.C.M.; Macedo, L.L.P.; Lucena, W.A.; Silva, M.S.; Antonino de Souza Junior, J.D.; Oliveira, G.R.; Quezado de Magalhaes, M.T.; Santiago, A.D.; et al. Variant Cry1Ia toxins generated by DNA shuffling are active against sugarcane giant borer. J. Biotechnol. 2010, 145, 215-221.

14. Oliveira, G.R.; Silva, M.C.M.; Lucena, W.A.; Nakasu, E.Y.T.; Firmino, A.A.P.; Beneventi, M.A.; Souza, D.S.L.; Gomes, J.E.; de Souza, J.D.; Rigden, D.J.; et al. Improving Cry8Ka toxin activity towards the cotton boll weevil (Anthonomuns grandis). BMC Biotechnol. 2011, 11, 1-13.

15. Bravo, A.; Gómez, I.; Porta, H.; García-Gomez, B.; Rodriguez-Almazan, C.; Pardo, L.; Soberón, M. Evolution of Bacillus thuringiensis Cry toxins insecticidal activity. Microb. Biotechnol. 2013, 6, $17-26$.

16. Stemmer, W. Rapid evolution of a protein in vitro by DNA shuffling. Nature (London) 1994, 370, 389-391.

17. Zhao, H.; Arnold, F. Optimization for DNA shuffling for high fidelity recombination. Nucleic Acids Res. 1997, 25, 1307-1308.

18. Crickmore, N.; Zeigler, D.; Feitelson, J.; Schnepf, E.; Rie, J.V.; Lereclus, D.; Baum, J.; Dean, D. Revision of the nomeclature for the Bacillus thuringiensis pesticidal crystal proteins. Microbiol. Molecular Biol. Rev. 1998, 62, 807-813.

19. Crickmore, N.; Baum, J.; Bravo, A.; Lereclus, D.; Narva, K.; Sampson, K.; Schnepf, E.; Sun, M.; Zeigler, D. Bacillus thuringiensis Toxin Nomeclature. Available online: http://www.btnomenclature.info/ (accessed on 2 May 2014).

20. Bravo, A.; Soberón, M.; Gill, S. Bacillus thuringiensis: Mechanisms and use. In Comprehensive Molecular Insect Science; Elsevier: Oxford, UK, 2005; Volume 6, pp. 175-206.

21. Bravo, A. Phylogenetic relationship of Bacillus thuringiensis $\delta$-endotoxin family proteins and their functional domains. J. Bacteriol. 1997, 179, 2793-2801.

22. De Maagd, R.A.; Bravo, A.; Crickmore, N. How Bacillus thuringiensis has evolved specific toxins to colonize the insect world. Trends Genet. 2001, 17, 193-199.

23. Crickmore, N. The diversity of Bacillus thuringiensis d-endotoxins. In Enthomopathogenic Bacteria: From Laboratory to Field Application; Charles, J.-F., Delécluse, A., Nielsen-LeRoux, C., Eds.; Kluwer Academic Publishers: Dordrecht, The Netherland, 2000; Volume 1, pp. 65-79.

24. Wu, J.-Y.; Zhao, F.-Q.; Bai, J.; Deng, G.; Qin, S.; Bao, Q.-Y. Adaptative evolution of cry genes in Bacillus thuringiensis: Implications for their specificity determination. Genomics Protemics Bioinform. 2007, 5, 102-110.

25. Schnepf, E.; Crickmore, N.; Rie, J.V.; Lereclus, D.; Baum, J.; Feitelson, J.; Zeigler, D.; Dean, D. Bacillus thuringiensis and its pesticidal crystal proteins. Microbiol. Mol. Biol. Rev. 1998, 62, 775-806.

26. Tuntitippawan, T.; Boonserm, P.; Katzenmeier, G.; Angsuthanasombat, C. Targeted mutagenesis of loop residues in the receptor-binding domain of the Bacillus thuringiensis Cry4Ba toxin affects larvicidal activity. FEBS Lett. 2005, 242, 325-332.

27. Aronson, A.; Shai, Y. Why Bacillus thuringienis insecticidal toxins are so effective: Unique features of their mode of action. FEMS Microbiol. Lett. 2001, 195, 1-8. 
28. Bravo, A.; Hendrickx, K.; Jansens, S.; Peferoen, M. Immunocytochemical analysis of specific binding of Bacillus thuringiensis insecticidal stal proteins to lepidopteran and coleopteran midgutmembranes. J. Invertebr. Pathol. 1992, 60, 247-253.

29. Bravo, A.; Gómez, I.; Muñoz-Garay, C.; Sánchez, J.; Miranda, R.; Zhuang, M.; Gill, S.; Sóberon, M. Oligomerization triggers binding of a Bacillus thuringiensis $1 \mathrm{Ab}$ pore-forming toxin to aminopeptidase $\mathrm{N}$ receptor leading to insertion into membrane microdomains. Biochim. Biophys. Acta 2004, 1667, 38-46.

30. Bravo, A.; Likitvivatanavong, S.; Gill, S.; Soberón, M. Bacillus thuringiensis: A story of a successful bioinsecticide. Insect Biochem. Mol. Biol. 2011, 41, 423-431.

31. De Maagd, R.A.; Bravo, A.; Berry, C.; Crickmore, N.; Schnepf, H. Structure diversity, and evolution of protein toxins from spore-forming entomopathogenic bacteria. Annu. Rev. Genet. 2003, 37, 409-433.

32. Chattopadhyay, A.; Bhatnagar, N.; Bhatnagar, R. Bacterial insecticidal toxins. Crit. Rev. Microbiol. 2004, 30, 33-54.

33. Jurat-Fuentes, J.; Adang, M. Toxin mode of action in susceptible and resistant Heliothis virescens larvae. J. Invertebr. Pathol. 2006, 92, 166-171.

34. Pigott, C.; Ellar, D. Role of receptors in Bacillus thuringiensis crystal toxin activity. Microbiol. Mol. Biol. Rev. 2007, 71, 255-281.

35. Pacheco, S.; Gomez, I.; Arenas, I.; Saab-Rincon, G.; Rodriguez-Almazan, C. Domain II loop 3 of Bacillus thuringiensis CrylAb toxin is involved in a "ping pong" binding mechanism with Manduca sexta aminopeptidase-N and cadherin receptors. J. Biol. Chem. 2009, 284, 32750-32757.

36. Soberón, M.; Pardo, L.; Muñoz-Garay, C.; Sánchez, J.; Gómez, I.; Porta, H.; Bravo, A. Pore formation by Cry toxins. Adv. Exp. Med. Biol. 2010, 677, 127-143.

37. Bravo, A.; Soberon, M. How to cope with insect resistance to Bt toxins? Trends Biotechnol. 2008, 26, 573-579.

38. Jiménez-Juárez, N.; Mu^noz-Garay, C.; Gómez, I.; Gill, S.; Soberón, M.; Bravo, A. The pore-pore from Bacillus thuringiensis Cry1 Ab toxin is necessary to induce insect death in Manduca sexta. Peptides 2008, 29, 318-323.

39. Pardo-López, L.; Muñoz-Garay, C.; Porta, H.; Rodríguez-Almazán, C.; Soberón, M.; Bravo, A. Strategies to improve the insecticidal activity of Cry toxins from Bacillus thruingiensis. Peptides 2009, 30, 589-595.

40. Soberón, M.; Gill, S.; Bravo, A. Signaling versus punching hole: How do Bacillus thuringiensis toxins kill insect midgut cells? Cell Mol. Life Sci. 2009, 66, 1337-1349.

41. Arenas, I.; Bravo, A.; Soberon, M.; Gomez, I. Role of alkaline phosphatase from Manduca sexta in the mechanism of action of Bacillus thuringiensis Cry1Ab toxin. J. Biol. Chem. 2010, 285, 12497-12503.

42. Gómez, I.; Dean, D.; Bravo, A.; Soberón, M. Molecular basis for Bacillus thuringiensis Cry1Ab toxin specificity: Two structural determinants in the Manduca sexta Bt-R1 receptor interact wit loops alpha8 and 2 in domain II of Cry1Ab toxin. Biochemistry 2003, 42, 10482-10489.

43. Gómez, I.; Arenas, I.; Benitez, I.; Miranda-Ríos, J.; Becerril, B.; Grande, G. Specific epitopes of domains II and III of Bacillus thuringiensis Cry1 Ab toxin involved in the sequential interaction with cadherin and aminopeptidase-N receptors in Manduca sexta. J. Biol. Chem. 2006, 281, 34032-34039. 
44. Marzari, R.; Edomi, P.; Bhatnagar, R.; Ahmad, S.; Selvapandiyan, A.; Bradbury, A. Phage display of Bacillus thuringiensis Cry1A(a) insecticidal toxin. FEBS Lett. 1997, 411, 27-31.

45. Kasman, L.; Lukowiak, A.; Garcynski, S.; McNall, R.; Youngman, P.; Adang, M. Phage display of a biologically active Bacillus thuringiensis toxin. Appl. Environ. Microbiol. 1998, 64, 2995-3003.

46. Vílchez, S.; Jacoby, J.; Ellar, D. Display of biologically functional insecticidal toxin on the surface of $\lambda$ phage. Appl. Environ. Microbiol. 2004, 70, 6587-6594.

47. Pacheco, S.; Gómez, I.; Sato, R.; Bravo, A.; Soberón, M. Functioinal display of Bacillus thuringiensis Cry1Ac toxin on T7 phage. J. Invertebr. Pathol. 2006, 92, 45-49.

48. Ishikawa, H.; Hoshino, Y.; Motoki, Y.; Kawahara, T.; Kitakima, M.; Kitami, M.; Watanabe, A.; Bravo, A.; Soberon, M.; Honda, A.; et al. A system for the directed evolution of the insecticidal protein from Bacillus thuringiensis. Mol. Biotechnol. 2007, 36, 90-102.

49. Lassner, M.; Bedbrook, J. Directed molecular evolution in plant improvement. Curr. Opin. Plant Biol. 2001, 4, 152-156.

50. Knight, J.; Broadwell, A.; Grant, W.; Shoemaker, C. A strategy for shiffling numerous Bacillus thuringiensis crystal protein domains. J. Econ. Entomol. 2004, 97, 1805-1813.

51. Shan, S.; Zhang, Y.; Ding, X.; Hu, S.; Sun, Y.; Yu, Z.; Liu, S.; Zhu, Z.; Xia, L. A Cry1Ac toxin variant generated by directed evolution has enhanced toxicity against Lepidopteran insects. Curr. Microbiol. 2011, 62, 358-365.

52. Fujii, Y.; Tanaka, S.; Otsuki, M.; Hoshino, Y.; Endo, H.; Sato, R. Affinity maturation of Cry1Aa toxin to the Bombys mori cadherin-like receptor by directed evolution. Mol. Biotechnol. 2013, $54,11$.

53. Soberón, M.; Pardo-López, L.; López, I.; Gómez, I.; Tabashnik, B.; Bravo, A. Engieering modified Bt toxins to counter insect resistance. Science 2007, 318, 1640-1642.

54. Alzate, O.; Osorio, C.; Florez, A.; Dean, D. Participation of valine 171 in $\alpha$-helix 5 of Bacillus thuringiensis $\mathrm{Cry} 1 \mathrm{Ab} \delta$-endotoxin in translocation of toxin into Lymantria dispar midgut membranes. Appl. Environ. Microbiol. 2010, 76, 7878-7880.

55. Vadlamudi, R.K.; Weber, E.; Ji, I.; Ji, T.H.; Bulla, L.A., Jr. Cloning and expression of a receptor for an insecticidal toxin of Bacillus thuringiensis. J. Biol. Chem. 1995, 270, 5490-5499.

56. Gomez, I.; Miranda-Rios, J.; Rudino-Pinera, E.; Oltean, D.I.; Gill, S.S.; Bravo, A.; Soberon, M. Hydropathic complementarity determines interaction of epitope (869)HITDTNNK(876) in Manduca sexta Bt-R(1) receptor with loop 2 of domain II of Bacillus thuringiensis Cry1A toxins. J. Biol. Chem. 2002, 277, 30137-30143.

57. Atsumi, S.; Inoue, Y.; Ishizaka, T.; Mizuno, E.; Yoshizawa, Y. Location of the Bombyx mori $175 \mathrm{kDa}$ cadherin-like protein-binding site on Bacillus thuringiensis Cry1Aa toxin. FEBS J. 2008, 275, 4913-4926.

58. Rajamohan, F.; Alzate, O.; Cotrill, J.A.; Curtiss, A.; Dean, D.H. Protein engineering of Bacillus thuringiensis $\delta$-endotoxin: Mutations at domain II of CryIAb enhance receptor affinity and toxicity toward gypsy moth larvae. Proc. Natl. Acad. Sci. USA 1996, 93, 14338-14343.

59. Pigott, C.; King, M.; Ellar, D. Investigating the properties of Bacillus thuringiensis Cry proteins with noval loop replacements created using combinatorial molecular biology. Appl. Environ. Microbiol. 2008, 74, 3497-3512. 
60. Abdullah, M.; Alzate, O.; Mohammad, M.; McNall, R.; Adang, M.; Dean, D. Introduction of Culex toxicity into Bacillus thuringiensis Cry4Ba by protein engineering. Appl. Environ. Microbiol. 2003, 69, 5343-5353.

61. Maagd, R.D.; Weemen-Hendriks, M.; Siekema, W.; Bosch, D. Domain III substitution in Bacillus thuringiensis $\delta$-endotoxin Cry1C domain III can function as a specific determinant for Spodoptera exigua in different, but not all, Cry1-Cry1C hybrids. Appl. Environ. Microbiol. 2000, $66,1559-1563$.

62. Naimov, S.; Weemen-Hendriks, M.; Dukiandjiev, S.; Maagd, R.D. Bacillus thuringiensis $\delta$-endotoxin Cryl hybrid proteins with increased activity against the Colorado potato beetle. Appl. Environ. Microbiol. 2001, 67, 5328-5330.

63. Walters, F.; deFontes, C.; Hart, H.; Warren, G.; Chen, J. Lepidopteran-active variable-region sequence imparts coleopteran activity in eCry3.1Ab, an engineered Bacillus thuringiensis hybrid insecticidal protein. Appl. Environ. Microbiol. 2010, 76, 3082-3088.

64. Hibbard, B.; Frank, D.; Kurtz, R.; Boudreau, E.; Ellersieck, M.; Odhiambo, J. Mortality impact of $\mathrm{Bt}$ transgenic maize roots expressing eCry3.1Ab, mCry3 A, and eCry3.1Ab plus mCry $3 \mathrm{~A}$ on western corn rootworm larvae in the field. J. Econ. Entomol. 2011, 104, 1584-1591.

65. Masson, L.; Lu, Y.; Mazza, A.; Brousseau, R.; Adang, M. The Cry1A(c) receptor purified from Manduca sexta displays multiple specificities. J. Biol. Chem. 1995, 270, 20309-20315.

66. Girard, F.; Vachon, V. Cysteine scanning mutagenesis of alpha4, a putative pore-lining helix of the Bacillus thuringiensis insecticidal toxin Cry1Aa. Appl. Environ. Microbiol. 2008, 74, 2565-2572.

67. Vachon, V.; Prefontaine, G. Helix 4 mutants of the Bacillus thuringiensis insecticidal toxin Cry1Aa display altered pore-forming abilities. Appl. Environ. Microbiol. 2004, 70, 6123-6130.

68. Jiménez-Juárez, N.; Muñoz-Garay, C.; Gómez, I.; Saab-Rincon, G.; Damian-Almazo, J.Y.; Gill, S.S.; Soberón, M.; Bravo, A. Bacillus thuringiensis Cry1Ab Mutants Affecting Oligomer Formation Are Non-toxic to Manduca sexta Larvae. J. Biol. Chem. 2007, 282, 21222-21229.

69. Rodríguez-Almazán, C.; Zavala, L.E.; Muñoz-Garay, C.; Jiménez-Juárez, N.; Pacheco, S.; Masson, L.; Soberón, M.; Bravo, A. Dominant negative mutants of Bacillus thuringiensis $\mathrm{Cry} 1 \mathrm{Ab}$ toxin function as anti-toxins: Demonstration of the role of oligomerization in toxicity. PLoS One 2009, 4, e5545.

70. Tigue, N.J.; Jacoby, J.; Ellar, D.J. The $\alpha$-Helix 4 Residue, Asn135, is involved in the oligomerization of Cry1Ac1 and Cry1Ab5 Bacillus thuringiensis toxins. Appl. Environ. Microbiol. 2001, 67, 5715-5720.

71. Alzate, O.; You, T. Effects of disulfide bridges in domain I of Bacillus thuringiensis Cry1Aa $\delta$-endotoxin on ion-channel formation in biological membranes. Biochemistry 2006, 45, 13597-13605.

72. Jenkins, J.L.; Lee, M.K.; Sangadala, S.; Adang, M.J.; Dean, D.H. Binding of Bacillus thuringiensis CrylAc toxin to Manduca sexta aminopeptidase-N receptor is not directly related to toxicity. FEBS Lett. 1999, 462, 373-376.

73. Sengupta, A.; Sarkar, A.; Priya, P.; Ghosh Dastidar, S.; Das, S. New insight to structure-function relationship of GalNAc mediated primary interaction between insecticidal Cry1Ac toxin and HaALP receptor of Helicoverpa armigera. PLoS One 2013, 8, e78249. 
74. De Maagd, R.A.; Bakker, P.L.; Masson, L.; Adang, M.J.; Sangadala, S.; Stiekema, W.; Bosch, D. Domain III of the Bacillus thuringiensis $\delta$-endotoxin Cry1Ac is involved in binding to Manduca sexta brush border membranes and to its purified aminopeptidase N. Mol. Microbiol. 1999, 31, 463-471.

75. Burton, S.; Ellar, D.; Li, J.; Derbyshire, D. $N$-acetylgalactosamine on the putative insect receptor aminopeptidase $\mathrm{N}$ is recognised by a site on the domain III lectin-like fold of a Bacillus thuringiensis insecticidal toxin. J. Mol. Biol. 1999, 287, 1011-1022.

76. Ning, C.; Wu, K.; Liu, C.; Gao, Y.; Jurat-Fuentes, J.L.; Gao, X. Characterization of a Cry1Ac toxin-binding alkaline phosphatase in the midgut from Helicoverpa armigera (Hubner) larvae. J. Insect Phys. 2010, 56, 666-672.

77. Grossi-de-Sa, M.; Magahães, M.; Silva, M.; Silva, S.; Dias, S.; Nakasu, E.; Brunetta, P.; Oliveira, G.; neto, O.O.; Oliveira, R.; et al. Susceptibility of Anthonomus grandis (cotton boll weevil) and Spodoptera frugiperda (fall armyworm) to a CrylIa-type toxin from a Brazilian Bacillus thuringiensis strain. J. Biochem. Moel. Biol. 2007,40, 10.

78. Schoder, M.; Poulsen, M.; Wilcks, A.; Kroghsbo, S.; Miller, A.; Frenzel, T.; Danier, J.; Rychlik, M.; Emami, K.; Gatehouse, A.; et al. A 90-day safety study of genetically modified rice expressing Cry1 Ab protein (Bacillus thuringiensis toxin) in Wistar rats. Food Chem. Toxicol. 2007, 45, 339-349.

79. Peng, D.; Chen, S.; Ruan, L.; Li, L.; Yu, Z.; Sun, M. Safety assessment of transgenic Bacillus thuringiensis with VIP insecticidal protein gene by feeding studies. Food Chem. Toxicol. 2007, 45, 1179-1185.

80. McClintock, J.; Schaffer, C.; Sjoblad, R. A comparative review of the mammalian toxicity of Bacillus thuringiensis-based pesticides. Pestic. Sci. 1995, 45, 95-105.

81. Guimarães, L.M.; Farias, D.F.; Muchagata, R.C.C.; de Magalhães, M.Q.; Campelho, C.C.; Rocha, T.L.; Vasconcelos, I.M.; Carvalho, A.F.U.; Mulinari, F.; Grossi-de-Sa, M.F. Short-term evaluation in growing rats of diet containing Bacillus thuringiensis Cryla12 entomotoxin: Nutritional responses and some safety aspects.J. Biomed. Biotechnol. 2010, 2010, 1-8.

82. Girard, F.; Vachon, V. Helix alpha 4 of the Bacillus thuringiensis Cry1Aa toxin plays a critical role in the post binding steps of pore formation. Appl. Environ. Microbiol. 2009, 75, 359-365.

83. Chen, X.; Curtiss, A.; Alcantara, E.; Dean, D. Mutations in domain I of Bacilllus thuringiensis $\delta$-endotoxin Cryl Ab reduce the irreversible binding of toxin to Manduca sexta brush border membrane vesicles. J. Biol. Chem. 1995, 270, 6412-6419.

84. Lin, X.; Parthasarathy, K.; Surya, W.; Zhang, T.; Mu, Y.; Torres, J. A conserved tetrameric interaction of cry toxin helix $\alpha 3$ suggests a funciontal role for toxin oligomerization. Biochim. Biophys. Acta 2014, 1838, 1777-1784.

85. Gomez, I.; Sanchez, J.; Miranda, R.; Bravo, A.; Soberon, M. Cadherin-like receptor binding facilitates proteolytic cleavage of helix $\alpha-1$ in domain I and oligomer pre-pore formation of Bacillus thuringiensis Cry1 Ab toxin. FEBS Lett. 2002, 513, 242-246.

86. Flores, H.; Soberón, X.; Sánches, J.; Bravo, A. Isolated domain II and III from the Bacillus thuringiensis Cry1 Ab $\delta$-endotoxin binds to lepidopteran midgut membranes. FEBS Lett. 1997, 414, 313-318.

87. Xiang, W.; Qiu, X.; Zhi, D.; Min, Z. N546 in b18-b19 loop is important for binding and toxicity of the Bacillus thuringiensis Cry1 Ac toxin. J. Invertabr. Pathol. 2009, 101, 119-123. 
88. Nakasu, E.; Firmino, A.; Dias, S.; Rocha, T.; Ramos, H.; Oliveira, G.; Lucena, W.; Carlini, C.; Grossi-de-Sa, M. Analysis of Cry8Ka5 binding proteins from Anthonomus grandis (Coleoptera: Curculionidae) midgut. J. Invertabr. Pathol. 2010, 104, 227-230.

89. Hofte, H.; Whiteley, H. Insecticidal crystal proteins of Bacillus thuringiensis. Microbiol. Rev. 1989, 53, 242-255.

90. Coux, F.; Vachon, V. Role of interdomain salt bridges in the pore-forming ability of the Bacillus thuringiensis toxins Cry1Aa and Cry1Ac. J. Biol. Chem. 2001, 276, 35546-35551.

91. Nunez-Valdez, M.; Sanchez, J.; Lina, L.; Guereca, L.; Bravo, A. Structural and functional studies of $\alpha$-helix 5 region from Bacillus thuringiensis Cry1Ab $\delta$-endotoxin. Biochim. Biophys. Acta 2001, 1546, 122-131.

92. Vachon, V.; Orefontaine, G. Role of helix 3 in pore formation by the Bacillus thuringiensis insecticidal toxin Cry1Aa. Biochemistry 2002, 41, 6178-6184.

93. Kanintronkul, Y.; Sramala, I.; Katzenmeier, G.; Panyim, S.; Angsuthanasombat, C. Specific mutations witihn the alpha4-alpha5 loop of Bacillus thuringiensis Cry4B toxin reveal a crucial role for Asn-166 and Tyr-170. Mol. Biotechnol. 2003, 24, 11-20.

94. Hank, S.K.; Quinn, A.M.; Hunter, T. The Protein Kinase Family: Conserved Features and Deduced Phylogeny of the Catalytic Domains. Science1988, 241, 42-52.

95. Pardo-Lopez, L.; Soberon, M.; Bravo, A. Bacillus thuringiensis insecticidal three-domain Cry toxins: Mode of action, insect resistance and consequences for crop protection. FEMS Microbiol. Rev. 2012, 37, 3-22.

96. Vachon, V.; Laprade, R.; Schwartz, J. Current models of the mode of action of Bacillus thuringiensis insecticidal crystal proteins: A critical review. J. Invertabr. Pathol. 2012, 111, 1-12.

97. Waksman, G.; Kominos, D.; Robertson, S.C.; Pant, N.; Baltimore, D.; Birge, R.B.; Cowburn, D.; Hanafusa, H.; Mayer, B.J.; Overduin, M.; et al. Crystal structure of the phosphotyrosine recognition domain $\mathrm{SH} 2$ of $v$-src complexed with tyrosine-phosphorylated peptides. Nature 1992, 358, 646-653.

98. Schulze-Gahmen, U.; de Bondt, H.L.; Kim, S.H. High-resolution crystal structures of human cyclin-dependent kinase 2 with and without ATP: Bound waters and natural ligand as guides for inhibitor design. J. Med. Chem. 1996, 39, 4540-4546.

99. Lv, Y.; Tang, Y.; Zhang, Y.; Xia, L.; Wang, F.; Ding, X. The role of b20-b21 loop structure in insecticidal activity of Cry1Ac toxin from Bacillus thuringiensis. Curr. Microbiol. 2011, 62, $665-670$.

100. Liu, Y.; Wang, Q.; Wang, F.; Ding, X.; Xia, L. Residue 544 in domain III of the Bacillus thuringiensis CrylAc toxin is involved in protein structure stability. Protein J. 2010, 29, 440-445.

101. Foundation, I.R. GM Crop Database. Available online: http://cera-gmc.org/index.php?action= gm_crop_database (accessed on 5 May 2014).

102. Bacher, J.; Reiss, B.; Ellington, A. Anticipatory evolution nd DNA shuffling. Genome Biol. 2002, 3, 1021:1-1021:4.

(C) 2014 by the authors; licensee MDPI, Basel, Switzerland. This article is an open access article distributed under the terms and conditions of the Creative Commons Attribution license (http://creativecommons.org/licenses/by/3.0/). 